\title{
Review of the Literature on Stress and Wellbeing of International Students in English-Speaking Countries
}

\author{
Eman S. Alharbi ${ }^{1}$ \& Andrew P. Smith ${ }^{1}$ \\ ${ }^{1}$ Centre for Occupational and Health Psychology, School of Psychology, Cardiff University, United Kingdom \\ Correspondence: Eman S. Alharbi, Centre for Occupational and Health Psychology, School of Psychology, Cardiff \\ University, 63 Park Place, Cardiff, CF10 3AS, United Kingdom. E-mail: Alharbie@cardiff.ac.uk; \\ SmithAP@cardiff.ac.uk
}

Received: November 1, 2017

Accepted: January 26, $2018 \quad$ Online Published: May 29, 2018

doi:10.5539/ies.v11n6p22

URL: https://doi.org/10.5539/ies.v11n6p22

\begin{abstract}
This review aims to address the major sources of stress experienced by international students, the role of individual differences, the chronology of their stress levels and wellbeing over time, and gaps in the existing literature. Two electronic databases (PubMed and Psych Info) were searched for English peer-reviewed articles using eight search terms. Thirty-eight studies were included in this paper and divided into themes and sub-themes including sources of stress, individual differences and mental health including stress, depression and wellbeing. The findings highlight major stressors and show mixed results in some areas due to the lack of homogenous samples based on country of origin or ethnicity and sometimes context differences concerning the country or university social dynamics. Limitations were identified in the methodology, and several recommendations for future research are included.
\end{abstract}

Keywords: international students, stress, wellbeing, wellbeing away, mental health

\section{Introduction}

Attending university as an international student can entail a variety of issues, such as separation from family, new responsibilities, financial concerns, finding a balance between studying, work and private life, and succeeding in academia. The process of studying abroad has many stages, beginning with preparing for a major life transition, adapting culturally and academically to the host country, addressing financial issues, maintaining social contacts with family and friends in the home country, creating a new social network in the host country, and ultimately returning home. Any of these stages can cause psychological conflict, overload and/or uncontrollability.

It is estimated that the number of international students around the world will reach 8 million by 2020, and universities in the UK could host over 850,000 international students by 2020 (British Council, 2004) International students represent a significant proportion of the higher education student enrolments and degree completions and provide many economic and cultural benefits to the host country. For example, in 2014 -2015 international students (EU and non-EU) made up 19\% of the student population in the UK universities and generated $£ 10$.8billion of UK export earnings; not only when they are domiciled in the UK, but also to their own countries after they return home.

The term, international students, has many synonyms, including overseas students and foreign students. The term 'international' is often used in the American literature, while 'overseas' and 'foreign' appears mainly in the British and Australian literature (Huang, 2008). The definition of international student by Kelo et al. (2006, p.210) is that of a student who takes an action to "study or to undertake other study-related activities" for "at least a certain unit of a study programme or a certain period of time", and "in the country to which they have moved". Moreover, Huang (2008) defined international students' as "students from a country outside of the UK, especially those coming from different cultural, language and religious backgrounds, some of which are very different from the host culture". Throughout this review, the term international student refers to students from one country who go to another country to earn an undergraduate or postgraduate degree.

Despite the high number of international students in the US and the contributions they have made to the US educational system and society, they have received limited attention within psychological research (Zhang \& Goodson, 2011). They also remain largely misunderstood in terms of adequate intervention methods to improve 
acculturation and prevent negative psychological outcomes. In previous literature reviews and systemic reviews, the number of articles that focus on this population-international students - has varied. The oldest review, conducted by Church (1982), focused on short-term visitors, or sojourners, and their psychological adjustment, and was one of the first to summarise the unique difficulties that international visitors may face. Later, Andrade (2006) reviewed the literature on factors that influence the adjustment and academic achievement of international students within several countries. Similarly, Zhang and Goodson (2011) reviewed 64 studies analysing the predictors of psychosocial adjustment of international undergraduate and graduate students in the United States. Smith and Khawaja (2011) also reviewed current acculturative models, when applied to international students. More recently, Wang and Xiao (2014) conducted a systemic review of 18 studies specifically on East Asian international students and their psychological well-being with 13 studies on Chinese international students.

Wellbeing, which is represented via various terms throughout psychological literature, has an important effect on health outcomes. Wellbeing includes having more positive feelings and fewer negative feelings. However, the dimensions of this concept are different per a wide range of theories and perspectives. Although universities, as well as other organisations, try to improve students' wellbeing and their positive feelings, there is still limited information about how to do so. Regarding international students, most studies and reviews are linked with practical acculturation strategies and attitudes.

The aforementioned reviews focused on acculturation and adjustment factors, including psychological adjustment or a single racial group. Therefore, our goals were to develop an understanding of the issues faced by international students by reviewing relevant articles published over the past 30 years (or longer), address areas of research not considered by other reviews and have an impact on individual stress levels and wellbeing. In addition, we aimed to identify gaps in the literature to suggest further research directions. International students are a diverse group, especially in the area of mental health. Due to our aims and the nature of the topic, we performed a narrative review instead of conducting a systematic review or meta-analysis, as this approach is comprehensive and covers a wide range of issues within the theme.

\section{Methods}

\subsection{Search Strategy}

A literature search was conducted using two databases: PubMed and PsycINFO. The following search terms were used: "international students", "overseas students", "foreign students", "studying aboard", "stress", "wellbeing", "mental health" and "psychological wellbeing" and combined these terms such as, wellbeing and international students. We limited our search to studies focused on international students in English-speaking countries (the US, the UK, Australia, New Zealand, Canada and Ireland) and peer-reviewed articles written in the English language published from 1806 to 2017. The search began in November 2016 and ended in March 2017.

\subsection{Study Selection}

Titles and abstracts of original research articles were screened with a focus on articles related to the topic of stress and wellbeing. We included full-time undergraduate and postgraduate students. Studies sampling from English-language schools and those including short-term and exchange students were excluded. Both quantitative and qualitative studies were included along with studies incorporating people of different ethnicities. Studies that only examined one race, such as East Asians or Blacks, were excluded.

\section{Results}

A total of 38 empirical studies were identified by the review with the majority of studies conducted in the United States $(n=24), 9$ studies conducted in Australia, 3 studies in New Zealand and 2 studies conducted in the UK. The earliest study was published in 1989 with the majority of studies conducted in the last 10 years indicating the recency of the international student phenomenon. Most of the studies entailed quantitative research designs with cross-sectional survey methods (75\%) and a few studies employing mixed methods, qualitative or longitudinal designs. The sample size varied for quantitative studies between 70 and 948 international students, whereas qualitative studies varied between 2 and 22 international students.

The following sections provided an evaluation of the 38 studies as they organised into themes and sub-themes: Sources of Stress, Individual Differences, and Mental Health: Stress and Wellbeing, some articles were included in more than one theme. Moreover, the nature of each study in terms of aims, location, sample, design, methods, and findings are summarised in the Appendix of this paper.

\subsection{Studies on Sources of Stress}

Herein, all sources of stress found in the literature that international students face are discussed, starting with the 
transition and being in a new environment or society with a different language and related problems (i.e. perceived racism), and ending with academic stress.

\subsubsection{Acculturative Stress}

When international students move from their home countries to a different country, they face a variety of challenges, including adjusting to a new environment. Thus, acculturative stress is the most common stressor discussed in the literature. Acculturative stress is one of the concepts used to understand psychosocial difficulties during acculturation; it is defined as "a stress reaction in response to life events that are rooted in the experience of acculturation" (Berry, 2006, p. 294).

Several factors have been identified that moderate the relationship between acculturation and stress including the nature of the host society, the type of acculturating group, the demographic and social characteristics of the immigrant group, and the psychological characteristics of the individual (Berry et al., 1987).

A range of studies reviewed in this paper (e.g., Poyrazli, Kavanaugh, Baker, \& Al-Timimi, 2004; Yeh \& Inose, 2003, 2010) used the same questionnaire to assess acculturative stress: The Acculturative Stress Scale for International Students (Sandhu \& Asrabadi, 1991, 1994, 1998). This questionnaire includes 36 items divided into seven subscales: Perceived Discrimination, Homesickness, Perceived Hate, Fear, Change, Guilt and Nonspecific. Chavajay and Skowronek (2008) used this questionnaire with four open-ended questions; however, the findings from the scale and the four open-ended questions were inconsistent, which demonstrated the need to apply a different methodology in order to understand the experience of international students.

Some studies have identified factors that contribute to the adjustment and less acculturative stress including geographic origin, English fluency, social connectedness, and satisfaction with one's social support network (Chavajay \& Skowronek, 2008). For example, Indian students showed lower acculturative stress than Chinese students when adjusting to living in the USA, presumably because they have greater familiarity with Western culture and society due to their generally stronger English language abilities (K. G. Rice, Choi, Zhang, Morero, \& Anderson, 2012). Moreover, Khawaja and Dempsey (2008) found students' self-perceptions and university environment expectations impacted significantly on their adjustment to a host culture for international studies.

Importantly, international students are cognisant of the fact that they will be returning home at the completion of their studies, such that the stress experienced through the acculturation process is temporary. Thus, students may be able to compartmentalise the acculturation experience by such actions as limiting their interactions with friends and family in their home country. In any case, it is likely that the stress sojourners experience related to acculturation may be less significant that immigrants who have to deal with a new environment and culture in the long term (Jung, Hecht, \& Wadsworth, 2007). Moreover, Hull (1978) argues that academic issues and concerns are more salient for international students and are the greater source of stress-related mental health problems (Yasuda \& Duan, 2002), rather than issues associated with cultural skills they may need to successfully interact with the host culture. Despite some findings to explain the acculturation process, Smith and Khawaja (2011) argue that current models are yet to fully account for the factors that may be associated with acculturation stress among international students.

\subsubsection{English-Language Proficiency}

English language proficiency is a clear factor and potential barrier to the adjustment of international students to living and studying in the US, UK, Australia and New Zealand. Low levels of English proficiency have important implications for academic achievement in terms of understanding lecture content, and success in oral and written exams. For example, Kim (2011) found the requirements to write assignments were considered the most difficult, and conducting in-class presentation or discussion were associated with high levels of anxiety among music therapy students in the US. Moreover, these international students often found it difficult to communicate with people in the host country in their everyday lives.

Despite the challenges of English language proficiency, O’Reilly, Ryan, and Hickey (2010) found that a high level of social support makes it easier for international students to make friends with people from the host country or from other countries. Furthermore, seeking help from a university's health services, which involves a high degree of English communication with a psychologist or health providers, can also make an international student's adjustment easier.

\subsubsection{Perceived Discrimination}

Feeling rejected by the people in the host country is also considered to be a source of stress for international students. For example, Chavajay and Skowronek (2008) reported that $48 \%$ of the sample, which consisted of 130 international students from 33 countries, experience being discriminated against by a member of the host culture, 
generally in places like a supermarket or at the university by the host country's students. Nilsson, Butler, Shouse, and Joshi (2008) examined perceived discrimination using the American-International Relations Scale (AIRS; Sodowsky \& Plake, 1991), which assesses the degree to which international students feel unaccepted by the people they encounter in the US. Their findings indicated a strong relationship between perceived prejudice and stress, which has a negative impact on wellbeing and self-esteem; making the adjustment process more difficult. Moreover, Wadsworth, Hecht, and Jung (2008) found that perceived race discrimination affects personal-enacted identity gaps. This occurs between the personal and enacted frames of identity when an individual perceives himself/herself in one manner but expresses himself/herself in a different manner while interacting with others (Jung \& Hecht, 2004).

A further study by Nilsson et al. (2008) found that international students may expect challenges in cultural differences with the host culture including language and communication barriers and issues with local customs. Nevertheless, international students are likely to be less prepared for encounters with prejudice or racism and may find they are not psychosocially equipped or ready to manage this experience. Indeed, Chen (1999) reported that managing and learning the ways to handle racial prejudice may be an important skill for the adjustment of international students to a host culture.

\subsubsection{Loneliness}

Loneliness may be a result of poor adjustment, low level of English language proficiency or perceived discrimination; however, the main reason why international students feel isolated or alone is because they are away from their family and/or friends. If some individuals found it difficult to make new friends in their home country, it can become even harder to do so when they live abroad. Some studies correlated loneliness with cultural distance, low English language proficiency and/or nationality. For instance, many Chinese students reported loneliness and homesickness as a concern during their first semester in the UK (Barron, Baum, \& Conway, 2007)

Sawir, Marginson, Deumert, Nyland, and Ramia (2008) interviewed 200 international students and found that 130 of the participants experienced loneliness and/or isolation, especially in the months immediately following their arrival in the host country. Sawir et al. (2008) also identified three kinds of loneliness experienced by international students: personal loneliness due to the loss of contact with their families; social loneliness, due to the loss of networks; and cultural loneliness, triggered by the absence of the preferred cultural and/or linguistic environment.

\subsubsection{Academic Stress}

Academic stress is commonly felt by students all over the world, whether they are studying in their home country or overseas. However, it seems that international students face more academic challenges than their domestic student peers due to the differences between the learning styles or teaching methodologies in their home country and the host country (Chavajay \& Skowronek, 2008; Irizarry, \& Marlowe, 2010; Sanders \& Lushington, 1999). For example, Asian students report a problem in applying their critical skills and the way they deal with staff or faculty (Mallinckrodt \& Leong, 1992).

International students also experience greater academic stress from frustration due to delays, lack of resources, failure to achieve goals and feeling like social outcasts, or from the pressure due to competition, deadlines, work, responsibilities and overload. Stress also occurs when too many changes, including rapid changes, disrupt a student's life and goals (Misra, Crist, \& Burant, 2003).However, Khawaja and Dempsey (2008) and Rice, Suh, Yang, Choe, and Davis (2016) found no significant differences in perceived academic stress between international students and domestic students in the US and Australia. Interestingly, Misra and Castillo (1995) found that US students reported a higher level of academic stress than international students. They found that this type of stress is more often self-imposed among US students compared to Asian international students. However, the international students may have answered questions in a socially desirable manner to avoid the stigma associated with admitting personal inadequacies.

Six studies focused on international students in one subject area, and most of them considered professional sciences, such as law, which is culture-based and requires an understanding of a specific culture in order to understand the legal system. This makes it difficult for international students that come from countries with a different culture and different values (Svarney, 1989). Other studies examined subject areas in which international students had to deal with patients or clients, such as nursing (Arty, Dns, \& Rady, 2002), clinical and counselling psychology (Nilsson, 2007), social work (Irizarry et al., 2010), dentistry (Sanders \& Lushington, 1999) and music therapy (Kim, 2011). International students may experience social anxiety, and sometimes clinical work is described as a stressful activity due to language difficulties and misunderstandings as well as the lack of familiarity with the culture, values and beliefs of the host country's health care system. A systemic review of international health care students found that a lack of cultural awareness had negative consequences on their performance 
(Mikkonen, Elo, Tuomikoski, \& Kääriäinen, 2016).

International students who study abroad usually have a high GPA in their home country. Consequently, they might believe that they can achieve the same level of academic excellence in the host country; these mismatched expectations can lead to stress and depression (Rosenthal, Russell, \& Thomson, 2008). Nevertheless, international students who report high academic competency and self-efficacy tend to experience less academic stress (Nilsson, 2007).

\subsection{Individual Differences}

The experience of studying abroad can vary for different people in terms of the factors that impact on them. Thus, the findings reported in previous research are sometimes inconsistent. All the common stressors that international students face have been discussed above; yet, the level of stress and a student's reaction to it could differ depending on the individual. Thus, this section of the paper will present a discussion of the main individual differences among international students that impact on their academic success and cultural adaptation.

\subsubsection{Key Demographic Variables (Gender, Age and Ethnicity)}

It has generally been found that younger students reported a higher level of stress and depression in comparison to older students. It has also been demonstrated by Mallinckrodt and Leong (1992) and Rosenthal et al. (2008), those female students were significantly more depressed and anxious than male students. Furthermore, male and female international students differed significantly in their health risk behaviours in reaction to stressors (smoking and alcohol consumption), with fewer women than men indicating that they smoke (defined as current use of any number of cigarettes) or consumed alcoholic beverages (had one drink within the last week).

In terms of ethnicity, in most of the reviewed studies the research sample consisted of East Asian students, especially Chinese students. Thus, only a limited number of studies included a sample of students with a different ethnicity or a sample with a variety of ethnicities. Typically, Chinese students comprised $40 \%$ of a study's sample. In comparing European and Asian students, Asians reported greater levels of acculturative stress (Kim, 2011; Poyrazli et al., 2004; Yeh \& Inose, 2003). This is likely because European and US societies tend to be considered Western cultures and, thus, fundamentally similar (Poyrazli et al., 2004), or it may be because Europeans encounter less racism and discrimination than Asians or Africans as they have a similar ethnicity and appearance (Yeh \& Inose, 2003). Furthermore, European students have less difficulty making friends from the host country and less difficulty speaking the host country's language than Asian students. However, when researchers compared African, Asian and Latino international students, the African students reported higher levels of acculturative stress and depression than other international students (Constantine, Okazaki, \& Utsey, 2004).

A further study by Szabo (2015) found that Asian students reported significantly less uprooting stress than Western students. That finding is consistent with the results reported by Fritz, Chin, and DeMarinis (2008) who found that being apart from their family is the most difficult stressor for European international students. Asian students also reported significantly lower levels of stress related to psychological disaster in comparison to Latino students. The authors suggested that this might possibly be due to the fact that cultural values related to how life is experienced and expressed may be different for Asians and Latinos and the limited number of Latino students at a university. Thus, the Latino students did not find many people from their culture, which had an impact on their ability to make friends and receive informal social support (Wilton \& Constantine, 2003).

\subsubsection{Coping Strategies}

Coping strategies are the ways in which people react to stressful situations. Lazarus (1993) defined coping as the "ongoing cognitive and behavioural efforts to manage specific external and/or internal demands that are appraised as taxing or exceeding the resources of the person" (p. 237). There are many different types of coping strategies, and their effectiveness depends on the type of stressors and individual encounters. The literature on international students discussed some of these different stressors and the role and the effectiveness of different strategies. For example, Tsenc and Newton (2001) interviewed African and Asian international students and reported that they used eight strategies to attain wellbeing and adjust to their new environment: knowing and understanding self and others, building friendships with peers and relationships with advisors, expanding individual worldview, asking for help when needed, English proficiency and letting problems go. Moreover, Szabo (2015) studied how international students cope with uprooting stress and found that primary coping predicted more symptoms of anxiety while secondary coping reduced the number of symptoms experienced over time and buffered the negative impact of stress.

In reaction to academic stress, Misra and Castillo (1995) found international students reported greater cognitive reactions (e.g. the use of some effective strategies to reduce stress), whereas US students reported behavioural 
reactions (e.g. smoking). Moreover, Misra et al. (2003) found female international students had more emotional reactions (i.e. fear and physiological symptoms, such as sweating, trembling, stuttering, body or headaches and weight loss or gain) and behavioural reactions (crying, self-abuse) to stressors than their male counterparts. The most frequent reactions to stressors among male students were cognitive; thus, their appraisal of stress was intellectual instead of emotional (Misra et al., 2003). Khawaja and Dempsey (2008) also examined how international students and Australian students cope with the challenges of university life, including academic stress. The findings indicated that international students used avoidance, repression and other passive coping strategies; however, this might be because the sample reported a high level of mismatched expectations.

Two studies examined religion as a coping strategy for stressful events. Specifically, Gardner, Krägeloh, and Henning (2014) and Hsu et al. (2009) found that religion/spirituality might function as a coping mechanism for international students in response to acculturation stress and perceived stress in general. However, the use of religious coping strategies among international Muslim students may decrease over time due to adapting to their new environment. Overall, research (e.g., Constantine et al., 2004; Lee et al., 2004; Tung, 2011; Wei et al., 2007) has shown the number of mental health problems experienced by international students (e.g., depression) is related to their ability to cope with stressors.

\subsubsection{Social Support}

An important means for international students to manage their transition to a new culture is the level of social support they experience. Social support may be conceptualised as the perceived comfort, caring, esteem, or help an individual has from other people or groups (Cobb, 1976). Social support comes primarily from one's family but entails peer groups, work colleagues and members of one's community. Several studies (Misra, Crist, \& Burant, 2003; Liu \& Winder, 2014; Poyrazli et al., 2004; Yeh \& Inose, 2003) show advantages of social support in facilitating adjustment and academic achievement and managing life stressors. For example, Neri and Ville (2008) found $25.8 \%$ of international students identified the support of family and close friends as being very important to their academic success.

Research in an Australian and American context (Hechanova-Alampay, Beehr, Christiansen, \& Van Horn, 2002; Khawaja \& Dempsey, 2008) revealed that international students reported lower levels of social support than domestic students; primarily due to the fact that domestic students lived with their parents or a close relative. Research has also shown that married students report higher levels of social support than students who were single (Poyrazli et al., 2004). Moreover, Praharso, Tear, and Cruwys (2017) argue that when people are far removed from people who provide help and care, the effectiveness of social support may be limited, especially for a life transition such as completing studies in a foreign country and culture.

Research has also shown that rather than the amount of social support, it is the quality and type of social support that alleviates any stress or strain felt by international students when they make the transition to a host culture (Hechanova-Alampay et al., 2002). Moreover, Mallinckrodt and Leong (1992) investigated different sources of social support amongst international graduate students in US, finding that positive relationships with university faculty members were especially beneficial for male students. In contrast, tangible support, positive relationships with other students, and flexibility in the curriculum were more beneficial for female students.

\subsubsection{Personality Traits}

Personality traits have a significant impact on how people feel about and react to a stressful situation. Some personality traits were discussed in the literature on international students, including perfectionism, self-critical perfectionism and maladaptive perfectionism. People with these perfectionism traits have been found to set high standards and high 'unrealistic' expectations of themselves and others. As such, there are often discrepancies between their expectations and their actual performance. Being hard with oneself and the fear of making a mistake has been found to be correlated with acculturative stress, GPA satisfaction, depression and stress (e.g., Hamamura \& Laird, 2014). Indeed, Huang and Mussap (2016), Nilsson et al. (2008) and Rice et al. (2012) found a significant positive association between self-critical perfectionism and depression and stress symptoms. Moreover, maladaptive perfectionism also increased the level of acculturative stress. Students that report a high level of maladaptive perfectionism are rarely satisfied with their GPA regardless of how academically proficient they objectively appear.

Neuroticism, which is the tendency to experience negative emotions, such as worry or fear, is another personality trait that can affect a student's level of stress. International students with a high level of neuroticism may experience higher degrees of stress due to the combination of neuroticism and acculturative stress; they may also experience more psychological distress, lower positive psychological adjustment and greater sociocultural difficulties. In contrast, openness is the tendency to appreciate new values, ideas or behaviours. International 
students who were more open to their new environment experienced less acculturative stress and were better able to adjust to their new surroundings; this may help them maintain a sense of wellbeing (Hirai, Frazier, \& Syed, 2015; Kim, 2011).

\subsubsection{Other Differences, Length of Stay}

Whereas it is assumed that greater adaptation of international students comes with them spending a longer time in a host culture (Adler, 1975; Church, 1982), the evidence would suggest otherwise. For example, Ward, Okura, Kennedy \& Kojima, (1998) and Ward and Rana-Dueba (1999) argue sociocultural adjustment may improve as a function of the length of stay, but the same cannot be said for psychological adjustment. Indeed, research has shown no significant effects on psychological adjustment relating to the length of an international student's stay in a foreign country (Rosenthal et al., 2008). Similarly, Nilsson et al., (2008) found the time spent in the United States was unrelated to stress amongst international students. In fact, Wilton and Constantine (2003) found lower levels of psychological adjustment were related to the greater length of stay in the U.S. by international students.

\subsection{Mental Health: Stress and Wellbeing}

This part of the paper discusses studies that have investigated the prevalence and causal factors on the stress, depression, well-being of international students.

\subsubsection{Perceived Stress}

Most researchers argue that stress is a natural part of being a student at a university due to the demands and change experienced. Additionally, either beginning or ending school/college is one of the 43 events on Holmes and Rahe's (1967) stress scale, which consists of life changes that have been linked to stress-related illness. During the first year of studies, and in subsequent years, both domestic and international students have similar difficulties in terms of time demands and academic stress. With international students, researchers tend to focus on specific types of stress, such as acculturative stress or academic stress. However, as previously mentioned, acculturation may lead to significant mental health implications for immigrants. Few studies have addressed the general degree of perceived stress or psychological distress amongst international students. Stress occurs when there is a discrepancy between the demands imposed by a situation and an individual's expectations. In this sense, stress can arise from both positive and negative events because individuals may process and perceive the same event differently due to differing cognitive appraisals. Therefore, stress depends on both primary and secondary appraisals: the primary appraisal indicates the perception of the situation, and the secondary appraisal reflects either abilities or resources for coping (Lazrus \& Folkamn, 1984).

The findings relating to stress among international students are mixed. In one study by Gardner et al. (2014), New Zealand international Muslim students and domestic students did not differ in terms of perceived stress. Similarly, Khawaja and Dempsey (2008) found no differences between local Australian and international students in their level of stress with both groups reporting similar degrees of emotional distress. Moreover, Pei et al. (2012) reported that the level of stress shown by international and domestic students in New Zealand was not significantly different from each other.

In contrast, Redfern (2016) found higher levels of stress in Chinese students compared to Australian students. The study entailed a mixed method design wherein students completed an open-ended item to describe the main sources of stress anxiety in their life and filled out the Depression Anxiety Stress Scale (DASS-42; Lovibond \& Lovibond, 1995b). Whereas the findings showed Australian students displayed 'normal' to 'mild' levels of depression and anxiety, stress levels were found to be 'mild' to 'moderate' in severity. In comparison, the Chinese international students reported significantly higher levels of stress and anxiety than Australian students, with both levels falling in the 'moderate' level of severity range (Lovibond \& Lovibond, 1995b).

A further study conducted by Fritz, Chin, and DeMarinis (2008) in the US also found higher levels of stress amongst Asian international students compared to European international students and those with US residency (students holding a green card). Although no differences were found between the three groups on their mood and irritability levels, Asian students reported significantly higher anxiety levels than European students. The authors concluded that Asian students might have reported higher levels of anxiety as a general cultural trait. However, it may also be the case that the measures employed in the study lack validity for assessing anxiety amongst people from an Asian background.

Research has also investigated international students' perceptions about the most significant situation to cause them stress. Chavajay and Skowronek (2008) asked 130 international students in the USA to report what situations in town or on the university campus caused them the most stress. The findings showed that $82 \%$ of the students reported concerns predominantly related to social life with $78 \%$ of students reporting feeling lonely. In another 
study, Redfern (2016) found Chinese students in Australia felt the main source of anxiety and stress were academic factors like their study workload and ambiguity over assessment tasks or teaching styles. Students also reported a range of life balance stressors, including a lack of time for relationships and social activities. There was also report of family stressors that entailed the high expectations and pressure to succeed that students felt from their parents.

A further source of stress reported in the literature is the perception of racial discrimination which may be defined as the excess stress to which individuals from stigmatised groups experience due to their minority position and cultural differences (Harrell, 2000). As argued by Wei, Ku, Russell, Mallinckrodt, and Liao (2008) racial discrimination is a distinct source of chronic stress for ethnic minorities that is additional to other general life stressors. In one study, Nilsson et al. (2008) found that perceived prejudice was the only variable that explained unique variance in stress among international students. Nevertheless, Cross (1995) reported that the stress associated with prejudice is moderated English proficiency, having friends from the host country and from the home country or previous travel to a different country.

Overall, it is generally accepted that stress is directly related to many medical conditions and long-term exposure to daily hassles is also associated with compromised health status of university students (Calicchia \& Graham, 2006; Kim \& Seidlitz, 2002). In one study, Hsu et al., (2009) investigated the physical symptoms of being away from home and friends amongst international students and employed the World Health Organization Quality of Life Questionnaire to determine their health-related quality of life in four different domains: physical, psychological, social, and environmental quality of life. Interestingly, the findings showed international students scored significantly lower than domestic students on the physical domain. However, stress was not assessed in the study such that it is not possible to determine whether international students had a lower physical quality of life due to their exposure to life stressors.

Finally, a study by Misra et al. (2003) put forward a model of stress for international students' population based on the conceptual domains of the stress process including primary and secondary stressors, stress mediators, and stress outcomes. The model further proposed direct and indirect relationships between the four constructs such that Primary stressors include life stressors, Secondary stressors include academic stressors, mediators include perceived social support to cope with these stressors, and reactions to stressors is the stress outcome that refers to the state of physiological or emotional arousal. The results of their investigation showed that higher levels of academic stressors were predicted by higher levels of life stress and by lower levels of social support. Moreover, higher academic stressors predicted greater reactions to stressors. Overall, the model accounted for a significant amount of variance in reactions to stressors $(82 \%)$ and all the regression paths in the model were statistically significant. Nevertheless, the model did not include some important aspects in the stress process such as individual difference factors like personality, prejudice and ethnicity which have also been shown to play an important role in the experience of stress among international students. Currently, there appears to be a gap in the literature, wherein no studies have adopted a multi-domain model to explain the stress experienced by international students. Indeed, there is a need to understand this stress by employing a model like the Demand, Resources and Individual Effects model (DRIVE), which includes individual differences, coping strategies and outcomes of perceived stress, such as anxiety and depression (Mark \& Smith, 2008).

\subsubsection{Depression}

Depression and anxiety are generally experienced when people are faced with adjusting to a new environment (Mesidor \& Sly, 2016; Mitchell, Greenwood, \& Gulielmi, 2007). Research has shown that depression is the most common presenting symptom with international students who have sought help from university counselling services (Wei, Ku, Russell, Mallinckrodt, \& Liao, 2008). Research findings have shown that the stress associated with acculturation, or acculturative stress is positively associated with depression (Rice et al., 2012). Similarly, acculturative stress has also been found to be directly associated with increased depressive symptoms (Constantine et al., 2004; Huang \& Mussap, 2016).

Research by Constantine et al. (2004) has also found that problems with English language fluency was negatively associated with depression, such that international students who rated their English skills as lower were more depressed. Depression among international students has additionally shown international students with a personal-enacted identity gap reported higher levels of depression. Such a finding suggests that expression of the self is an important factor in the mental health status of an international student; perhaps over and above appraisals from others (Jung et al., 2007). Yet, some international students like those with an Asian background find it difficult to distinguish between emotional distress and somatic complaints (Mori, 2000). This phenomenon may be a confounding factor in why Asian students utilise college health centres for stress-related problems more frequently than American students (Misra \& Castillo, 1995). 


\subsubsection{Well-Being}

The focus in the research has generally been on stressors and psychological problems faced by international students, however, this research often neglects uncovering the more positive factors that facilitate health and well-being within the International students' experience (Outhred \& Chester, 2013). In the literature pertaining to students in higher education in general and international students specifically, little is known about wellbeing. Additionally, it is not clear what factors play important roles in maintaining positive wellbeing and limiting negative feelings. Of the 38 articles, only five partially discussed wellbeing. Wellbeing is a multifaceted concept, subjective wellbeing (SWB) includes three elements: life satisfaction, positive effects and negative effects, which are related to emotions and mood. By contrast, psychological wellbeing (PWB), as Ryff and Singer (2008) defined it, constitutes six aspects: self-acceptance, purpose in life, environmental mastery, positive relationships, personal growth and autonomy (Dodge, Daly, Huyton, \& Sanders, 2012). Moreover, the model of cross-cultural adjustment by Ward and Searle (1991) includes psychological and sociocultural dimensions, wherein psychological adjustment is defined as psychological wellbeing or satisfaction in a new cultural environment, and sociocultural adjustment refers to an individual's ability to 'fit in' or interact with members of the host culture.

Findings from a longitudinal study on adjustment of international students by Cemalcilar and Falbo (2008) showed that a positive acculturation was associated with sociocultural adaptation rather than psychological well-being or academic adaptation. Furthermore, a comparison between Asian American and Asian international students revealed that ethnic identity, rather than acculturation, predicted Asian American students' emotional well-being, and neither ethnic identity nor acculturation predicted Asian international students' emotional wellbeing (Yasuda \& Duan, 2002). Research has also shown that participating in a club inside or outside of a university, or building friendships with people on or off campus, could improve the average student's level of general wellbeing (Neri \& Ville, 2008), whereas identity loss could decrease wellbeing (Praharso et al., 2017).

All the studies that discussed wellbeing among international students considered that feeling happy or establishing and maintaining good social networks were just part of a student's sense of wellbeing; they emphasised that wellbeing is multi-dimensional. Moreover, studies often used a five-point Likert scale to rate the level of wellbeing, such as the level of depression or the level of happiness. However, the studies in this review neglected important aspects of students' wellbeing, particularly in terms of a university's courses and environment and how these aspects affect their feelings, either positively or negatively.

In a further study (Cho \& Yu, 2015) investigated the role the University organisational support systems may play in the well-being of international students. It was assumed that international students are heavily dependent on the host university in various ways making the host university the most important source of support. The model put forward included four dimensions including university identification, university support, school-life satisfaction, and psychological stress. The findings demonstrated the positive effects of university support on two dimensions of international students' psychological well-being: increased international students' school-life satisfaction and a reduction in their psychological stress. It was also found that university identification positively affected international students' perception of university support and ultimately their school-life satisfaction. In contrast, there was no significant effect of university identification on psychological stress. Although this study focused on school life satisfaction it did not provide information on the effect of university support on well-being.

Finally, the Sodexo Quality of Life Services (2014) proposed a model of wellbeing called wellbeing away. It was originally designed for people working away from their home and contains five phases. Each phase or stage includes factors that influence the level of an individual's wellbeing, either negatively or positively.

The model proposes five phases of transition commencing with Pre-departure planning, which includes developing expectations about being away, acknowledging that the coming separation is real, setting up a support network and, more importantly, planning for contacting and communicating with family at home. The researcher raises the idea that with current technology people tend to think that technology will mitigate the separation. However, that is not the case when the person is away and working long hours with little free time.

The second phase is called Being away and includes two main factors: the first includes using technology without over-reliance on it. The second involves developing the ability to unwind from work or study, as it is known that dwelling on work- or study-related issues lead to negative effects and other health-related problems. The model also emphasises changing activities and doing something different from studying. For example, it is better for a student to exercise in their free time rather than doing something similar to what they usually do such as surfing the internet.

The third phase is called Preparing to return and has a real impact on wellbeing. One important thing to realise is that people (both the person who is away from home and their family or friends) change, even over short periods of 
time and that has an impact at the level of wellbeing. One factor that could help at this stage is to change activities before returning home.

The fourth phase entails Returning, which is the last stage of being away. Increasing the amount of leisure or relaxation time is important. This point is particularly important for people in conflict zones (i.e., soldiers), but may not be as important for international students.

The final stage is Being back. When a student is back at home, they need to readjust to their home country. Disconnections between being back and feeling psychologically back affect the level of wellbeing.

Although this model makes practical sense, it does highlight the importance of pre-transition preparation to a new country and culture. Indeed, very few studies have considered the pre-arrival stage of international students when they make a transition. There would appear to be a gap in the literature on how pre-planning of their transition affects the level of stress and wellbeing experienced by international students when they eventually settle into a host culture. This model is worth examining as it considers many aspects of being away from home.

\subsubsection{Chronology of the Level of Stress and Wellbeing}

Golden (1973) stated that the psychological moods of students rise and fall with the academic calendar. However, that assessment is not completely accurate for international students. Irizarry and Marlowe (2010) found that students experienced the highest levels of academic and social stress during their first year, but these levels decreased as their university experience progressed. Typically, the first four months of the transition for international students can be socially and psychologically challenging (Fritz et al., 2008). A longitudinal content study by Cemalcilar and Falbo (2008) found significant declines among international students' psychological wellbeing after completing about three months of their first year of study in the US. The level of happiness or wellbeing increases with time; $48.6 \%$ of international students in Australia reported that they felt happier as their university experience progressed than they did when they first began their studies (Neri \& Ville, 2008).

\section{Conclusions and Further Research}

This literature review aimed to evaluate studies examining stress and wellbeing among international students. The review addressed the different types of stressors faced by international students, and some of the individual differences that play an important role in moderating both stress levels and wellbeing. The review also discussed studies examining the correlation between stress and wellbeing. From this analysis, it can be seen that the majority of studies focused on how well international students adjust to their host culture and the factors impacting their stress levels. Although adapting or adjusting to a new environment is an important general factor in mental health, there are debates around the importance of international students adjusting compared to immigrants for example. However, the lack of studies applying stress and wellbeing interventions or considering all dimensions of these concepts do not enable us to fully understand international students' experiences. The reviewed studies were limited in revealing the stressors potentially related to studying at a specific university or the outcomes of the experience of studying abroad. More importantly, the studies lacked knowledge regarding the factors that play a role in international students' wellbeing; only one study discussed the role of the university.

The findings show various inconsistencies in focus areas due to reasons such as the lack of a homogenous sample based on country of origin or ethnicity. For example, most of the studies included students from Asian countries, specifically Chinese students, who represent the largest population; however, these results cannot be generalized to other ethnicities. Furthermore, differences exist regarding the country or university's society (some universities have a large number of international students while others have a limited number) and the host country society. In addition, there was a lack of validation of the scales used to evaluate student responses in some studies.

This review has led to several recommendations for future research on the psychological impact of studying in a different county or culture on international students. Further research would be appropriate to investigate the stress and wellbeing effects experienced by international students. The research should address all relevant dimensions of these concepts and apply models or theories to understand this subjective experience. Factors such as quality of university life and study-life balance should be investigated.

Regarding methodology, there is a real need to employ a mixed methods research design to understand the experience of international students. Moreover, longitudinal research designs (which are highly limited) are also needed. Such studies should examine the experiences of international students before they arrive in their host country, their expectations, their university experiences, how stress levels and wellbeing change over time and the possible impact of different factors. Finally, more comparative studies are needed between international students and domestic students. This approach would provide greater insight into how the experiences of studying in university and health outcomes differ between groups. Moreover, it could lead to innovative solutions for 
difficulties faced by either group.

\section{References}

Adler, P. S. (1975). The transitional experience: An alternative view of culture shock. Journal of Humanistic Psychology, 15(4), 13-23. https://doi.org/10.1177/002216787501500403

Barron, P., Baum, T., \& Conway, F. (2007). Learning, living and working: Experiences of international postgraduate students at a Scottish university. Journal of Hospitality and Tourism Management, 14(2), 85-101. https://doi.org/10.1375/jhtm.14.2.85

Berry, J. W. (2006). Acculturative stress. In P. T. P. Wong, \& L. C. J. Wong (Eds.), Handbook of multicultural perspectives on stress and coping (pp. 287-298). Dallas: Spring Publications. https://doi.org/10.1007/0-387-26238-5_12

British Council. (2004). Vision 2020 Forecasting International Student Mobility: A UK Perspective. London: British Council. Retrieved from http://www.britishcouncil.org/eumd_-_vision_2020.pdf

Calicchia, J. A., \& Graham, L. B. (2006). Assessing the relationship between spirituality, life stressors, and social resources: Buffers of stress in graduate students. North American Journal of Psychology, 8(2), 307-320.

Carty, R, O’Grady, E, Wichaikhum, O., \& Bull, J. (2002). Opportunities in preparing global leaders in nursing. Journal of Professional Nursing, 18(2), 70-77. https://doi.org/10.1053/jpnu.2002.123725

Cemalcilar, Z., \& Falbo, T. (2008). A Longitudinal Study of the Adaptation of International Students in the

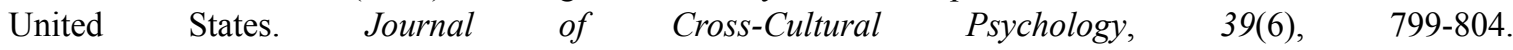
https://doi.org/10.1177/0022022108323787

Chavajay, P., \& Skowronek, J. (2008). Aspects of acculturation stress among international students attending a university in the USA. Psychological Reports, 103, 827-835. https://doi.org/10.2466/pr0.103.3.827-835

Chen, C. P. (1999). Common stressors among international college students: Research and counseling implications. Journal of College Counseling, 2, 49-65. https://doi.org/10.1002/j.2161-1882.1999.tb00142.x

Cho, J., \& Yu, H. (2015). Roles of University Support for International Students in the United States: Analysis of a Systematic Model of University Identification, University Support, and Psychological Well-Being. Journal of Studies in International Education, 19(1), 11-27. https://doi.org/10.1177/1028315314533606

Church, A. T. (1982). Sojourner adjustment. Psychological Bulletin, 91(3), 540-572. http://dx.doi.org/10.1037/0033-2909.91.3.540

Cobb, S. (1976). Social support as a moderator of life stress. Psychosomatic Medicine, 38(5), 300-314. https://doi.org/10.1097/00006842-197609000-00003

Constantine, M. G., Okazaki, S., \& Utsey, S. O. (2004). Self-concealment, social self-efficacy, acculturative stress, and depression in African, Asian, and Latin American international college students. The American Journal of Orthopsychiatry, 74(3), 230-241. https://doi.org/10.1037/0002-9432.74.3.230

Cross, S. E. (1995). Self-Construals, Coping, and Stress in Cross-Cultural Adaptation. Journal of Cross-Cultural Psychology, 26(6). https://doi.org/10.1177/002202219502600610

Dodge, R., Daly, A. P., Huyton, J., \& Sanders, L. D. (2012). The challenge of defining wellbeing. International Journal of Wellbeing, 2, 222-235. https://doi.org/10.5502/ijw.v2i3.4

Fritz, M. V., Chin, D., \& DeMarinis, V. (2008). Stressors, anxiety, acculturation and adjustment among international and North American students. International Journal of Intercultural Relations, 32(3), 244-259. https://doi.org/10.1016/j.ijintrel.2008.01.001

Gardner, T. M., Krägeloh, C. U., \& Henning, M. A. (2014). Religious coping, stress, and quality of life of Muslim university students in New Zealand, 17(4), 327-338.

Golden, J. S. (1973). Student adjustment abroad: A psychiatrist's view. International Educational and Cultural Exchange, 8(4), 28-36.

Hamamura, T., \& Laird, P. G. (2014). The Effect of Perfectionism and Acculturative Stress on Levels of Depression Experienced by East Asian International Students, 42(October), 205-217. https://doi.org/10.1002/j.2161-1912.2014.00055.x

Harrell, S. P. (2000). A Multidimensional Conceptualization of Racism-Related Stress: Implications for the Well-Being of People of Color. American Journal of Orthopsychiatry, 70(1), 42-57 
https://doi.org/10.1037/h0087722

Hechanova, R., Beehr, T. A., Christiansen, N. D., \& Van Horn, R. K. (2003). Adjustment and strain among domestic and international student sojourners: A longitudinal study. School Psychology International, 23(4): 458-475. https://doi.org/10.1177/0143034302234007

Hirai, R., Frazier, P., \& Syed, M. (2015). Psychological and sociocultural adjustment of first-year international students: Trajectories and predictors. Journal of Counseling Psychology, 62(3), 438-452. https://doi.org/10.1037/cou0000085

Holmes, T. H., \& Rahe, R. H. (1967). The social readjustment rating scale. Journal of psychosomatic research, 11, 213. https://doi.org/10.1016/0022-3999(67)90010-4

Hsu, P. H., Krägeloh, C. U., Shepherd, D., \& Billington, R. (2009). Religion/spirituality and quality of life of international tertiary students in New Zealand: An exploratory study. Mental Health Religion \& Culture, 12(4), 385-399. https://doi.org/10.1080/13674670902752920

Huang, R. (2008). Mapping Educational Tourists Experience in the UK: understanding international students Mapping Educational Tourists' Experience in the UK : Understanding international students. Third World Quarterly, 29(5), 1003-1020. https://doi.org/10.1080/01436590802106247

Huang, S. L., \& Mussap, A. J. (2016). Maladaptive Perfectionism, Acculturative Stress and Depression in Asian International University Students. Journal of Psychologists and Counsellors in Schools, 1-12. https://doi.org/10.1017/jgc.2016.18

Hull, W. F., IV. (1978). Foreign students in the United States of America. New York, NY: Praeger

Hunt, E. N., Martens, M. P., Wang, K. T., \& Yan, G. C. (2016). Acculturative stress as a moderator for international student drinking behaviors and alcohol use consequences. Journal of Ethnicity in Substance Abuse, 3, 263-275. https://doi.org/10.1080/15332640.2016.1185656

Irizarry, C., \& Marlowe, J. (2010). Beyond Mere Presence-Making Diversity Work. Social Work Education, 29(1), 96-107. https://doi.org/10.1080/02615470902838760

Jung, E., Hecht, M. L., \& Wadsworth, B. C. (2007). The role of identity in international students' psychological well-being in the United States: A model of depression level, identity gaps, discrimination, and acculturation. International Journal of Intercultural Relations, 31(5), 605-624. https://doi.org/10.1016/j.ijintrel.2007.04.001

Khawaja, N. G., \& Dempsey, J. (2008). A Comparison of International and Domestic Tertiary Students in Australia. Journal of Psychologists and Counsellors in Schools, 18(1), 30-46. https://doi.org/10.1375/ajgc.18.1.30

Kim, S.-A. (2011). Predictors of acculturative stress among international music therapy students in the U.S. Music Therapy Perspectives, 29(2), 126-132. https://doi.org/10.1093/mtp/29.2.126

Kim, Y., \& Seidlitz, L. (2002). Spirituality moderates the effect of stress on emotional and physical adjustment. Personality and Individual Differences, 32(8), 1377-1390. https://doi.org/10.1016/S0191-8869(01)00128-3

Lazarus, R. S. (1993). Coping theory and research: Past, present, and future. Psychosomatic Medicine, 55, 2324-2347. https://doi.org/10.1097/00006842-199305000-00002

Lazarus, R. S., \& Folkman, S. (1984). Stress, appraisal, and coping. New York: Springer Pub. Co.

Leong, F. T., Mallinckrodt, B., \& Kralj, M. M. (1990). Cross-cultural variations in stress and adjustment among Asian and Caucasian graduate students. Journal of Multicultural Counseling and Development, 18(1), 19-28. https://doi.org/10.1002/j.2161-1912.1990.tb00433.x

Liu, D. W. Y., \& Winder, B. (2014). Exploring foreign undergraduate students' experiences of university. International Journal of Qualitative Studies in Education, 27(1), 42-64. https://doi.org/10.1080/09518398.2012.736643

Lovibond, P. F., \& Lovibond, S. H. (1995a). The structure of negative emotional states: Comparison of the Depression Anxiety Stress Scales (DASS) with the Beck Depression and Anxiety Invento-ries. Behavioural Research Therapy, 33(3), 335-343. https://doi.org/10.1016/0005-7967(94)00075-U

Lovibond, S. H., \& Lovibond, P. F. (1995b). Manual for the depression anxiety stress scales (psychology foundation monograph). Sydney: School of Psychology, University of New South Wales.

Mallinckrodt, B., \& Leong, F. T. L. (1992). International Graduate Students, Stress and Social Support. Journal 
of College Student Development, 33(1), 71-78.

Maria Kelo, Ulrich Teichler, Bernd Wächter,Toward Improved Data on Student (2006), Mobility in Europe: Findings and Concepts of the Eurodata Study. Journal of Studies in International Education, 10(3), 194-223. https://doi.org/10.1177/1028315306288755

Mark, G. M., \& Smith, A. P. (2008). Stress models: A review and suggested new direction. EA-OHP series.

Mesidor, J. K., \& Sly, K. F. (2016). Factors that Contribute to the Adjustment of International Students. Journal of International Students, 6(1), 262-282.

Mikkonen, K., Elo, S., Tuomikoski, A.-M., \& Kääriäinen, M. (2016). Mentor experiences of international healthcare students' learning in a clinical environment: A systematic review. Nurse Education Today, 40, 87-94. https://doi.org/10.1016/j.nedt.2016.02.013

Misra, R., \& Castillo, L. G. (1995). Academic Stress Among College Students: Comparison of American and International Students. International Journal of Stress Management, 11(2), 132-148. https://doi.org/10.1037/1072-5245.11.2.132

Misra, R., Crist, M., \& Burant, C. J. (2003). Relationships Among Life Stress, Social Support, Academic Stressors, and Reactions to Stressors of International Students in the United States. International Journal of Stress Management, 10(2), 137-157. https://doi.org/10.1037/1072-5245.10.2.137

Mitchell, S., Greenwood, A. K., \& Gulielmi, M. C. (2007). Utilization of counseling services: Comparing international and U.S. college students. Journal of College Counseling, 10, 117-130. https://doi.org/10.1002/j.2161-1882.2007.tb00012.x

Neri, F., \& Ville, S. (2008). Social capital renewal and the academic performance of international students in Australia. Journal of Socio-Economics, 37(4), 1515-1538. https://doi.org/10.1016/j.socec.2007.03.010

Nilsson, J. E. (2007). International Students in Supervision: Course Self-Efficacy, Stress, and Cultural Discussions in Supervision. The Clinical Supervisor, 26(1/2), 35-47. https://doi.org/10.1300/J001v26n01_04

Nilsson, J. E., Butler, J., Shouse, S., \& Joshi, C. (2008). The Relationships among Perfectionism, Acculturation, and Stress in Asian International Students. Journal of College Counseling, 11(2), 147-158. https://doi.org/10.1002/j.2161-1882.2008.tb00031.x

Outhred, T., \& Chester, A. (2013). Improving the International Student Experience in Australia Through Embedded Peer Mentoring. Mentoring \& Tutoring: Partnership in Learning, 21(3), 312-332. https://doi.org/10.1080/13611267.2013.851499

Poyrazli, Senel, Philip R. Kavanaugh, Adria Baker, and Nada AlTimimi. (2004). Social Support and Demographic Correlates of Acculturative Stress in International Students. Journal of College Counseling, 7, 73-82. https://doi.org/10.1002/j.2161-1882.2004.tb00261.x

Praharso, N. F., Tear, M. J., \& Cruwys, T. (2017). Stressful life transitions and wellbeing: A comparison of the stress buffering hypothesis and the social identity model of identity change. Psychiatry Research, 247(January), 265-275. https://doi.org/10.1016/j.psychres.2016.11.039

Redfern, K. (2016). An empirical investigation of the incidence of negative psychological symptoms among Chinese international students at an Australian university. Australian Journal of Psychology, 68(4), 281-289. https://doi.org/10.1111/ajpy.12106

Rice, K. G., Choi, C.-C., Zhang, Y., Morero, Y. I., \& Anderson, D. (2012). Self-Critical Perfectionism, Acculturative Stress, and Depression Among International Students. The Counseling Psychologist, 40(4), 575-600. https://doi.org/10.1177/0011000011427061

Rice, K. G., Suh, H., Yang, X., Choe, E., \& Davis, D. E. (2016). The Advising Alliance for International and Domestic Graduate Students: Measurement Invariance and Implications for Academic Stress. Journal of Counseling Psychology, 63(3), 331-342. https://doi.org/10.1037/cou0000141

Rosenthal, D. A., Russell, J., \& Thomson, G. (2008). The health and wellbeing of international students at an Australian university. Higher Education, 55(1), 51-67. https://doi.org/10.1007/s10734-006-9037-1

Sanders, A. E., \& Lushington, K. (1999). Sources of stress for Australian dental students. J Dent Educ, 63(9), 688-697.

Sawir, E., Marginson, S., Deumert, A., Nyland, C., \& Ramia, G. (2008). Loneliness and International Students: 
An Australian Study. Journal of Studies in International Education, 12(2), 148-180. https://doi.org/10.1177/1028315307299699

Sodexo Quality of Life Services. (2014). Wellbeing away. London. England: Sodexo Quality of Life Services.

Svarney, R. J. (1989). Counselling foreign law students. Journal of Counselling and Development, 68, 228-231 https://doi.org/10.1002/j.1556-6676.1989.tb01364.x

Szabo, A. (2015). Uprooting Stress, Coping, and Anxiety: A Longitudinal Study of International Students. International Journal of Stress Management, 23(2), 190-208. https://doi.org/10.1037/a0039771

Tsenc, W., \& Newton, F. B. (2001). International students' strategies for well-being. College Student Journal, 36(4), 591-598.

Wadsworth, B. C., Hecht, M. L., \& Jung, E. (2008). The Role of Identity Gaps, Discrimination, and Acculturation in International Students' Educational Satisfaction in American Classrooms. Communication Education, 57(1), 64-87. https://doi.org/10.1080/03634520701668407

Ward, C., \& Rana-Deuba, A. (1999). Acculturation and adaptation revisited. Journal of Cross Cultural Psychology, 30(4), 422-442. https://doi.org/10.1177/0022022199030004003

Ward, C., Okura, A., Kennedy, A., \& Kojima, T. (1998). The U-curve on trial: A longitudinal study of psychological and sociocultural adjustment during cross-cultural transition. International Journal of Intercultural Relations, 22(3), 277-291. https://doi.org/10.1016/S0147-1767(98)00008-X

Wei, M., Ku, T., Russell, D. W., Mallinckrodt, B., \& Liao, K. Y. (2008). Moderating Effects of Three Coping Strategies and Self-Esteem on Perceived Discrimination and Depressive Symptoms: A Minority Stress Model for Asian International Students, 55(4), 451-462. https://doi.org/10.1037/a0012511

Wilton, L., \& Constantine, M. G. (2003). Length of residence, cultural adjustment difficulties, and psychological distress symptoms in Asian and Latin American international college students. Journal of College Counseling, 6(2), 177-186. https://doi.org/10.1002/j.2161-1882.2003.tb00238.x

Yasuda, T., \& Duan, C. (2002). Ethnic Identity, Acculturation, and Emotional Well-being among Asian American and Asian International Students. Asian Journal of Counselling, 9(2), 1-26.

Yeh, C. J., \& Inose, M. (2003). International students' reported English fluency, social support satisfaction, and social connectedness as predictors of acculturative stress. Counselling Psychology Quarterly, 16(1), 15-28. http://dx.doi.org/10.1080/0951507031000114058

Zhang, K. C., \& Zhang, A. (2016). Dare to Dream: Personal Values, Life Goals, and International Students in New Zealand. Journal of Religion and Health, 56(5), 1503-1514. https://doi.org/10.1007/s10943-016-0307-7

\section{Appendix}

Table 1. Matrix of 38 reviewed articles

\begin{tabular}{|c|c|c|c|c|c|c|}
\hline Authors & Location & Aim & $\begin{array}{c}\text { Sample } \\
\text { nationality and } \\
\text { size }\end{array}$ & Design & Measurements & Findings \\
\hline (Svarney, 1989) & $\begin{array}{l}\text { United } \\
\text { States }\end{array}$ & $\begin{array}{l}\text { To understand issues } \\
\text { faced by foreign } \\
\text { students studying law }\end{array}$ & Review article & Review & Review & $\begin{array}{l}\text { Law student face some } \\
\text { similar challenges to other } \\
\text { international students but } \\
\text { unique issues due to their } \\
\text { field of study }\end{array}$ \\
\hline
\end{tabular}




\begin{tabular}{|c|c|c|c|c|c|c|}
\hline $\begin{array}{l}\text { (Mallinckrodt \& } \\
\text { Leong, 1992) }\end{array}$ & $\begin{array}{l}\text { United } \\
\text { States }\end{array}$ & $\begin{array}{l}\text { To investigate the level } \\
\text { of stressors and stress } \\
\text { symptoms amongst } \\
\text { international students } \\
\text { and the sources of } \\
\text { social support that } \\
\text { might be the most } \\
\text { useful coping with } \\
\text { stressors. }\end{array}$ & $\begin{array}{l}\text { Graduate } \\
\text { international } \\
\text { students from } \\
\text { different } \\
\text { ethnicities and } \\
\text { countries } \\
n=105\end{array}$ & Quantitative & $\begin{array}{l}\text { A 48-item Life event survey } \\
\text { scale; The 33-item Bell Global } \\
\text { Psychopathology scale } \\
\text { (symptoms of stress and } \\
\text { depression); A } 58 \text {-item } \\
\text { measure of physical health } \\
\text { symptoms; The educational } \\
\text { system services (social } \\
\text { support from the academic } \\
\text { program); A 19-item measure } \\
\text { of Quality of family life }\end{array}$ & $\begin{array}{l}\text { All types of social support } \\
\text { reduced anxiety, depression } \\
\text { and physical symptoms of } \\
\text { stress. Relations with } \\
\text { faculty members were } \\
\text { particularly beneficial for } \\
\text { men, whereas tangible } \\
\text { support, relations with other } \\
\text { students for women. }\end{array}$ \\
\hline $\begin{array}{c}\text { (Misra \& Castillo, } \\
1995)\end{array}$ & $\begin{array}{l}\text { United } \\
\text { States }\end{array}$ & $\begin{array}{l}\text { Compare perceptions } \\
\text { of academic stressors } \\
\text { and reactions to these } \\
\text { stressors between } \\
\text { American and } \\
\text { international students }\end{array}$ & $\begin{array}{l}\text { American } \\
\text { students } n=249 \\
\text { international } \\
\text { students } n=143\end{array}$ & Cross-sectional & $\begin{array}{lll}\text { Academic } & \text { Stress } & \text { Scale } \\
\text { (51-items). } & & \end{array}$ & $\begin{array}{l}\text { International students } \\
\text { reported lower academic } \\
\text { stress and fewer reactions to } \\
\text { stressors than American } \\
\text { students. Differences in } \\
\text { reaction to stress by gender } \\
\text { were also found. }\end{array}$ \\
\hline (Cross, 1995) & $\begin{array}{l}\text { United } \\
\text { States }\end{array}$ & $\begin{array}{l}\text { Examined differences } \\
\text { in the independent and } \\
\text { interdependent } \\
\text { self-construals of } \\
\text { American and East } \\
\text { Asian students and the } \\
\text { influence of these } \\
\text { self-construals on } \\
\text { coping and stress. }\end{array}$ & $\begin{array}{l}\text { First } \quad \begin{array}{l}\text { year } \\
\text { students: }\end{array} \\
\text { East } \\
\text { Asian } n=71 \\
\text { American } n=79\end{array}$ & $\begin{array}{l}\text { A cross-sectional } \\
\text { study as a part of } \\
\text { a larger } \\
\text { longitudinal } \\
\text { project }\end{array}$ & $\begin{array}{l}\text { The Ego task subscale; 2-itme } \\
\text { direct coping (describe a } \\
\text { situation and how did you deal } \\
\text { with it); Relationship } \\
\text { satisfaction measure; language } \\
\text { ability and a measure of } \\
\text { perceived stress. }\end{array}$ & $\begin{array}{l}\text { The self-construals and } \\
\text { direct coping were the } \\
\text { strongest predictors of stress } \\
\text { for East Asian students. } \\
\text { Other variables commonly } \\
\text { identified in research } \\
\text { addressing cross-cultural } \\
\text { adaptation (e.g., number of } \\
\text { host country friends, } \\
\text { relationships } \\
\text { co-nationals, language } \\
\text { ability, and previous } \\
\text { cross-cultural experience) } \\
\text { did not significantly predict } \\
\text { stress for the international } \\
\text { students. }\end{array}$ \\
\hline $\begin{array}{c}\text { (Sanders \& } \\
\text { Lushington, 1999) }\end{array}$ & Australia & $\begin{array}{l}\text { Investigated sources of } \\
\text { stress among dental } \\
\text { students and the } \\
\text { relationship between } \\
\text { stress and academic } \\
\text { performance. }\end{array}$ & $\begin{array}{l}\text { Australian } \\
\text { students } n=161 \\
\text { international } \\
\text { students } n=43\end{array}$ & Quantitative & $\begin{array}{l}\text { A } 38 \text { items the Dental } \\
\text { Environnent } \\
\text { questionnaire. } \\
\text { Scholastic performance was } \\
\text { measured by students grades. }\end{array}$ & $\begin{array}{l}\text { Limited support for the } \\
\text { negative effect of stress on } \\
\text { academic performance and } \\
\text { that may be due to the } \\
\text { measuring tools used. } \\
\text { International students } \\
\text { expressed significantly more } \\
\text { stress than demotics in } \\
\text { terms of language, social } \\
\text { isolation and learning styles. }\end{array}$ \\
\hline $\begin{array}{l}\text { (Tsenc \& Newton, } \\
\text { 2001) }\end{array}$ & $\begin{array}{l}\text { United } \\
\text { States }\end{array}$ & $\begin{array}{l}\text { To discover strategies } \\
\text { and coping skills } \\
\text { intentional student use } \\
\text { to adjust and maintain } \\
\text { wellbeing }\end{array}$ & $\begin{array}{l}\text { Two } \\
\text { international } \\
\text { students: } \\
\text { African and } \\
\text { Asian }\end{array}$ & $\begin{array}{l}\text { Qualitative; } \\
\text { semi- structed } \\
\text { Interview. }\end{array}$ & $\begin{array}{l}\text { What is wellbeing and how to } \\
\text { cope with difficulties? }\end{array}$ & $\begin{array}{l}\text { Students used } 8 \text { strategies: } \\
\text { knowing and understanding } \\
\text { self and others, build } \\
\text { friendship and relationship } \\
\text { with advisors, expand } \\
\text { individual worldview, } \\
\text { asking for help when } \\
\text { needed, English proficiency, } \\
\text { use the tactic of "letting go" }\end{array}$ \\
\hline
\end{tabular}




\begin{tabular}{|c|c|c|c|c|c|c|}
\hline $\begin{array}{c}\text { (Arty, Dns, \& Rady, } \\
\text { 2002) }\end{array}$ & $\begin{array}{l}\text { United } \\
\text { States }\end{array}$ & $\begin{array}{l}\text { Investigated issues } \\
\text { facing international } \\
\text { nursing doctoral } \\
\text { students in the US }\end{array}$ & $\begin{array}{l}\text { Students } n=184 \\
\text { from } 27 \\
\text { countries. and } \\
\text { students } n=5 \\
\text { from Thailand, } \\
\text { Egypt and Saudi } \\
\text { Arabia } \\
\text { participated in a } \\
\text { focus group. }\end{array}$ & $\begin{array}{l}\text { Mixed method } \\
\text { (survey and } \\
\text { focus group) }\end{array}$ & $\begin{array}{l}\text { Online survey to identify areas } \\
\text { of study, how they applied that } \\
\text { knowledge on graduation, } \\
\text { dissertation topic and } \\
\text { challenges. Focus Group to } \\
\text { discuss challenges. }\end{array}$ & $\begin{array}{l}\text { Students faced issues } \\
\text { include language problems, } \\
\text { financing, lack of support } \\
\text { systems and familiarity with } \\
\text { the U.S. health care system } \\
\text { and stress from a heavy } \\
\text { course load. }\end{array}$ \\
\hline $\begin{array}{l}\text { Hechanova-Alampay, } \\
\text { Beehr, Christiansen, } \\
\text { \& Van Horn (2002) }\end{array}$ & $\begin{array}{l}\text { United } \\
\text { States }\end{array}$ & $\begin{array}{l}\text { Investigated the } \\
\text { relationship between } \\
\text { adjustment and distress } \\
\text { or strain responses } \\
\text { during the first six } \\
\text { months of study }\end{array}$ & $\begin{array}{l}\text { Domestic } \\
\text { students } n=188 \\
\text { international } \\
\text { students } n=106 \\
\text { from } \quad 37 \\
\text { countries. }\end{array}$ & $\begin{array}{l}\text { Longitudinal } \\
\text { cross-sectional } \\
\text { study with } 3 \\
\text { phases of data } \\
\text { collection over } \\
\text { six months }\end{array}$ & $\begin{array}{l}\text { 14-item Adjustment scale } \\
\text { (Black \& Stephens, 1989); } \\
\text { Depression Scale (Radloff, } \\
\text { 1977) 12-item from the } \\
\text { cultural adaptation pain scale } \\
\text { (CAPS); 10-item Self-efficacy } \\
\text { scale (Harrison, 1996); } 10 \\
\text { items } \\
\text { culture distance questions } \\
\text { (Bilker et al., 1980); 8-item } \\
\text { Social support scale (Ray \& } \\
\text { Miller, 1994); } 8 \text { items to } \\
\text { measure amount of interaction } \\
\text { with the host nation. }\end{array}$ & $\begin{array}{l}\text { No significant different } \\
\text { between groups on level of } \\
\text { strain at time } 1 \text { (beginning } \\
\text { the semester). } \\
\text { International student } \\
\text { sojourners had greater } \\
\text { difficulty in adjusting } \\
\text { during their initial transition } \\
\text { into the university. } \\
\text { Self-efficacy positively } \\
\text { correlated with adjustment } \\
\text { and negatively with strain. }\end{array}$ \\
\hline $\begin{array}{l}\text { (Yasuda \& Duan, } \\
\text { 2002) }\end{array}$ & $\begin{array}{l}\text { United } \\
\text { States }\end{array}$ & $\begin{array}{l}\text { Investigated the } \\
\text { acculturation, ethnic } \\
\text { identity, and emotional } \\
\text { well-being, of Asian } \\
\text { American and Asian } \\
\text { international students. }\end{array}$ & $\begin{array}{l}\text { Asian American } \\
n=63 \\
\text { Asian } \\
\text { international } \\
\text { students } n=55\end{array}$ & Quantitative & $\begin{array}{l}\text { The 12-item Multigroup } \\
\text { Ethnic Identity Measure } \\
\text { (Roberts et al., 1999); The } \\
\text { 21-item Suinn-Lew Asian } \\
\text { Self-Identity Acculturation } \\
\text { Scale (Suinn, } \\
\text { Rickard-Figueroa, et al., } \\
\text { 1987); } \\
\text { The } \\
\text { Depression-Happiness Scale } \\
\text { (McGreal \& Joseph, 1993) }\end{array}$ & $\begin{array}{l}\text { Asian American students } \\
\text { scored higher in } \\
\text { acculturation than Asian } \\
\text { international students. Asian } \\
\text { American and Asian } \\
\text { international students } \\
\text { differed in acculturation } \\
\text { level and ethnic identity, but } \\
\text { not in emotional well- } \\
\text { being. }\end{array}$ \\
\hline $\begin{array}{l}\text { (Misra, Crist \& } \\
\text { Burant, 2003) }\end{array}$ & $\begin{array}{l}\text { United } \\
\text { States }\end{array}$ & $\begin{array}{l}\text { Examined the } \\
\text { relationships among } 4 \\
\text { constructs: life stress, } \\
\text { academic stressors, } \\
\text { perceived social } \\
\text { support, and reactions } \\
\text { to stressors. }\end{array}$ & $\begin{array}{l}\text { International } \\
\text { students from } \\
\text { Africa, Asia, and } \\
\text { the Middle East } \\
n=143\end{array}$ & Cross-sectional & $\begin{array}{l}\text { The Index of Life Stress ( } 31 \\
\text { items); Student-Life Stress } \\
\text { Inventory ( } 51 \text { items), and The } \\
\text { Index of Social Support } \\
\text { (40-items) }\end{array}$ & $\begin{array}{l}\text { Women exhibited higher } \\
\text { reactions to stressors than } \\
\text { men. Women had higher } \\
\text { emotional and physiological } \\
\text { reactions to stressors while } \\
\text { men had higher cognitive } \\
\text { reactions. Higher levels of } \\
\text { academic stressors were } \\
\text { predicted by higher levels of } \\
\text { life stress and by lower } \\
\text { levels of social support. }\end{array}$ \\
\hline $\begin{array}{c}\text { (Wilton \& } \\
\text { Constantine, 2003) }\end{array}$ & $\begin{array}{l}\text { United } \\
\text { States }\end{array}$ & $\begin{array}{l}\text { To understand the } \\
\text { relationships among } \\
\text { length of stay in the } \\
\text { US., cultural } \\
\text { adjustment difficulties, } \\
\text { and psychological } \\
\text { distress in a sample of } \\
\text { Asian and Latin } \\
\text { American students }\end{array}$ & $\begin{array}{l}\text { Asians } n=66 \\
\text { Latinos } n=34\end{array}$ & Quantitative & $\begin{array}{l}\text { The 59-item CADC scale to } \\
\text { assesses the stressors } \\
\text { associated with acculturation; } \\
\text { The 33-item General } \\
\text { Psychological Distress } \\
\text { Checklist }\end{array}$ & $\begin{array}{l}\text { Latin American students } \\
\text { reported significantly higher } \\
\text { levels of psycho- logical } \\
\text { distress compared Asians. } \\
\text { Greater length of stay in the } \\
\text { U.S. was associated with } \\
\text { lower levels of } \\
\text { psychological distress. } \\
\text { Higher acculturative distress } \\
\text { predicted higher levels of } \\
\text { psychological distress. }\end{array}$ \\
\hline
\end{tabular}




\begin{tabular}{|c|c|c|c|c|c|c|}
\hline (Yeh \& Inose, 2003) & $\begin{array}{l}\text { United } \\
\text { States }\end{array}$ & $\begin{array}{l}\text { To what extent do } \\
\text { international students' } \\
\text { age, gender, English } \\
\text { fluency, social } \\
\text { connectedness and } \\
\text { social support network } \\
\text { satisfaction predict } \\
\text { acculturative distress. }\end{array}$ & $\begin{array}{l}\text { International } \\
\text { undergraduate } \\
\text { and graduate } \\
\text { students } n=372\end{array}$ & Cross-sectional & $\begin{array}{l}\text { The 36-item Acculturative } \\
\text { Stress Scale for International } \\
\text { Students (Sandhu \& Asrabadi, } \\
\text { 1994); The 8-item Social } \\
\text { Connectedness Scale (Lee \& } \\
\text { Robbins, 1995); The 6-item } \\
\text { Social Support } \\
\text { Questionnaire-Short Form } \\
\text { (Sarason et al., 1987). }\end{array}$ & $\begin{array}{l}\text { Europen students } \\
\text { experienced less } \\
\text { acculturative stress other. } \\
\text { English fluency, social } \\
\text { support satisfaction, and } \\
\text { social connectedness were } \\
\text { all predictors } \\
\text { acculturative stress. }\end{array}$ \\
\hline $\begin{array}{c}\text { (Constantine, } \\
\text { Okazaki, \& Utsey, } \\
\text { 2004) }\end{array}$ & $\begin{array}{l}\text { United } \\
\text { States }\end{array}$ & $\begin{array}{l}\text { To examine } \\
\text { self-concealment } \\
\text { behaviours and social } \\
\text { self-efficacy skills as } \\
\text { potential mediating } \\
\text { factors in the } \\
\text { relationship between } \\
\text { acculturative stress and } \\
\text { depression. }\end{array}$ & $\begin{array}{l}\text { International } \\
\text { students } n=320, \\
25.3 \% \text { African, } \\
42.5 \% \text { Asian, } \\
\text { and } 32.2 \% \\
\text { Latino. }\end{array}$ & Cross-sectional & $\begin{array}{l}\text { Questions about English } \\
\text { language use and the 10-item } \\
\text { Self-Concealment Scale } \\
\text { (Larson \& Chastain, 1990); } \\
\text { The 6-itme Social } \\
\text { Self-Efficacy Scale (Sherer \& } \\
\text { Adams, 1983); the 36-item } \\
\text { Acculturative Stress Scale for } \\
\text { International Students } \\
\text { (Sandhu \& Asrabadi, 1994); } \\
\text { the 20-item Center for } \\
\text { Epidemiologic } \\
\text { Studies-Depression Scale } \\
\text { (Radloff, 1977). }\end{array}$ & $\begin{array}{l}\text { A strong relationship } \\
\text { between acculturative stress } \\
\text { and depression. African } \\
\text { international students } \\
\text { reported higher levels of } \\
\text { acculturative stress and } \\
\text { depression than other } \\
\text { international students. }\end{array}$ \\
\hline
\end{tabular}

Workload, English language and exams were main issues

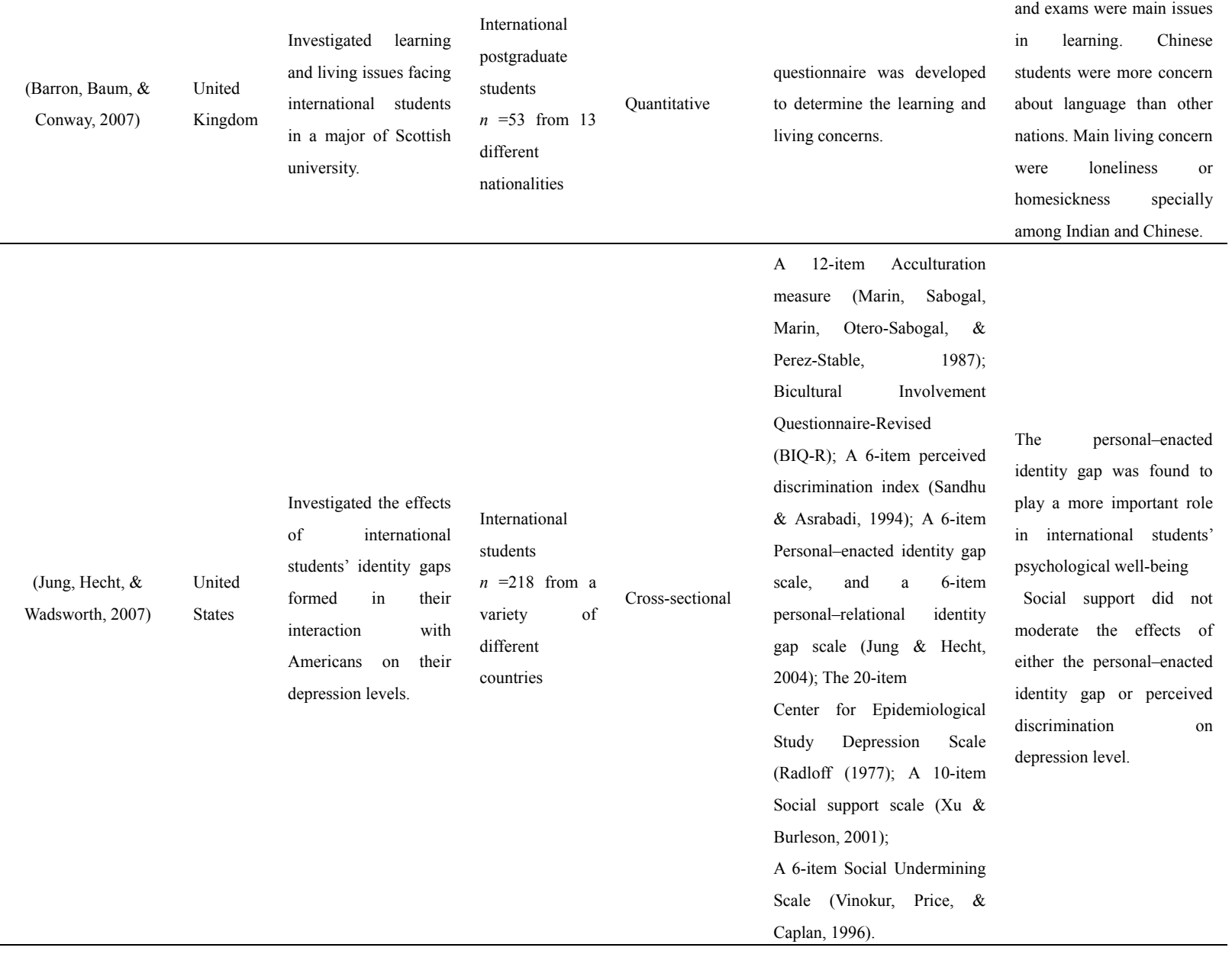




\begin{tabular}{|c|c|c|c|c|c|c|}
\hline (Nilsson, 2007) & $\begin{array}{l}\text { United } \\
\text { States }\end{array}$ & $\begin{array}{l}\text { Investigated the } \\
\text { relationship among } \\
\text { academic and } \\
\text { supervision variables } \\
\text { for international } \\
\text { students in counselling } \\
\text { psychology. }\end{array}$ & $\begin{array}{l}\text { International } \\
\text { students } n=73 \\
\text { from } 6 \text { world } \\
\text { continents }\end{array}$ & Cross-sectional & $\begin{array}{l}\text { The 21-item College Stress } \\
\text { Inventory; The 12-item } \\
\text { Counsellor Rating Short } \\
\text { Form; The 20-item College } \\
\text { Self-Efficacy Inventory; The } \\
\text { 17-item International Student } \\
\text { Supervision Scale }\end{array}$ & $\begin{array}{l}\text { High academic or course } \\
\text { self-efficacy was associated } \\
\text { with less academic stress. }\end{array}$ \\
\hline $\begin{array}{c}\text { (Cemalcilar \& Falbo, } \\
\text { 2008) }\end{array}$ & $\begin{array}{l}\text { United } \\
\text { States }\end{array}$ & $\begin{array}{l}\text { Investigated how the } \\
\text { acculturation strategies } \\
\text { adopted before the } \\
\text { transition affected the } \\
\text { psychological and } \\
\text { well-being students } \\
\text { adaptation of } \\
\text { after the international } \\
\text { transition. }\end{array}$ & 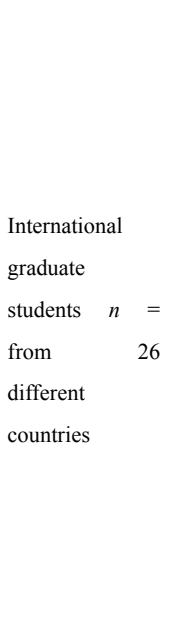 & $\begin{array}{l}\text { Longitudinal } \\
\text { with } 2 \text { phases: } \\
\text { before arriving } \\
\text { and after } 21 \\
\text { weeks. }\end{array}$ & $\begin{array}{l}\text { The Acculturation } \\
\text { Index by Ward and } \\
\text { Rana-Deuba (1999); A } \\
\text { 19-item to assess four } \\
\text { strategies of acculturation. A } \\
\text { measure of psychological } \\
\text { well-being (Hudson, 1987); } \\
\text { The 18-item Generalized } \\
\text { Contentment Scale to measure } \\
\text { well-being; The } \\
\text { 15-item Sociocultural } \\
\text { Adaptation Scale (Ward \& } \\
\text { Kennedy, (1994); An 8-item } \\
\text { academic adaptation } \\
\text { developed by the researchers. }\end{array}$ & $\begin{array}{l}\text { No advantage for the } \\
\text { bicultural adopting strategy } \\
\text { before the transition and } \\
\text { students who had expressed } \\
\text { a separation strategy before } \\
\text { the transition had } \\
\text { significantly lower social } \\
\text { adaptation. } \\
\text { most of the students } \\
\text { experienced significant } \\
\text { declines in their } \\
\text { psychological well-being } \\
\text { after completing } 3 \text { months. }\end{array}$ \\
\hline $\begin{array}{c}\text { (Chavajay \& } \\
\text { Skowronek, 2008) }\end{array}$ & $\begin{array}{l}\text { United } \\
\text { States }\end{array}$ & $\begin{array}{l}\text { To understand the } \\
\text { stress international } \\
\text { students experience } \\
\text { living in a new cultural } \\
\text { community }\end{array}$ & $\begin{array}{l}\text { International } \\
\text { students }(n= \\
\text { 130) from } 33 \\
\text { different } \\
\text { countries }\end{array}$ & Mixed methods & $\begin{array}{l}\text { Acculturative Stress Scale; } \\
\text { Four open-ended questions to } \\
\text { determine if students felt they } \\
\text { were } \\
\text { treated differently, what } \\
\text { stressful situations affect their } \\
\text { life, what causes them the } \\
\text { most stress living in town } \\
\text { and/or attending the } \\
\text { university, and under what } \\
\text { circumstances are they lonely? }\end{array}$ & $\begin{array}{l}\text { Participants reported lower } \\
\text { level of acculturation stress. } \\
\text { The findings were mixed } \\
\text { between the scales and the } \\
\text { four open-ended questions } \\
\text { specially, in perceived } \\
\text { discrimination. }\end{array}$ \\
\hline $\begin{array}{c}\text { (Fritz, Chin, \& } \\
\text { DeMarinis, 2008) }\end{array}$ & $\begin{array}{l}\text { United } \\
\text { States }\end{array}$ & $\begin{array}{l}\text { To test if international } \\
\text { students experience } \\
\text { anxiety, irritability, and } \\
\text { stress being apart from } \\
\text { family and friends, } \\
\text { school pressure, } \\
\text { language, work and } \\
\text { financial difficulties } \\
\text { than students with } \\
\text { permanent US } \\
\text { residency. }\end{array}$ & $\begin{array}{l}\text { Asians } \quad n=71 \\
\text { Europeans } n=40 \\
\text { permanent } \quad \text { US } \\
\text { residents. } n=97\end{array}$ & $\begin{array}{l}\text { Mixed method } \\
\text { (Questionnaire } \\
\text { and open-ended } \\
\text { questions) }\end{array}$ & $\begin{array}{l}\text { The 15-item anxiety scale } \\
\text { (Derogatis, 1977); The } \\
\text { Student Differential } \\
\text { Questionnaire to rate mood } \\
\text { level and difficulties with } \\
\text { language, social differences, } \\
\text { being apart from family and } \\
\text { friends, making new friends, } \\
\text { and not being able to work. } \\
\text { Students also reported their } \\
\text { help-seeking behaviours } \\
\text { (friends, family, psychologist, } \\
\text { God or no one) }\end{array}$ & $\begin{array}{l}\text { Difficulties among Asian } \\
\text { students were in language } \\
\text { and to make friends, while } \\
\text { European students found } \\
\text { being apart from family as } \\
\text { the stressful. } \\
\text { Asian students } \\
\text { significantly higher on the } \\
\text { anxiety. All three groups } \\
\text { reported a level of change in } \\
\text { anxiety, irritability and } \\
\text { mood. }\end{array}$ \\
\hline
\end{tabular}




\begin{tabular}{|c|c|c|c|c|c|c|}
\hline $\begin{array}{c}\text { (Khawaja \& } \\
\text { Dempsey, 2008) }\end{array}$ & Australia & $\begin{array}{l}\text { To compare } \\
\text { international and } \\
\text { domestic students on } \\
\text { demographic variables, } \\
\text { accommodation and } \\
\text { financial satisfaction, } \\
\text { social and academic } \\
\text { stressors, mismatched } \\
\text { expectations, } \\
\text { dysfunctional coping } \\
\text { and psychological } \\
\text { distress. }\end{array}$ & $\begin{array}{l}\text { Domestic } n=86 \\
\text { international } \\
n=86\end{array}$ & Cross-sectional & $\begin{array}{l}\text { Housing Scale (2-iems); } \\
\text { Financial Scale (2 items); } \\
\text { 6-item Academic Situation } \\
\text { Scale; 22-item Servqual Scale } \\
\text { to measure students' } \\
\text { perception of the university's } \\
\text { service quality; 10-itme Brief } \\
\text { Cope Scale; 25-item Personal } \\
\text { Resource Questionnaire Scale } \\
\text { assessing perceived social } \\
\text { support; Hopkins Symptom } \\
\text { Checklist (62-item scale, } \\
\text { measures psychological } \\
\text { distress }\end{array}$ & $\begin{array}{l}\text { International students } \\
\text { showed lower levels of } \\
\text { social support, higher } \\
\text { mismatched expectations } \\
\text { and greater use of } \\
\text { dysfunctional coping } \\
\text { strategies which placed } \\
\text { them in a more vulnerable } \\
\text { situation than the domestic } \\
\text { students. }\end{array}$ \\
\hline $\begin{array}{c}\text { Nilsson, Butler, } \\
\text { Shouse \& Chetan } \\
\text { (2008) }\end{array}$ & $\begin{array}{l}\text { United } \\
\text { States }\end{array}$ & $\begin{array}{l}\text { Investigated the } \\
\text { relationship between } \\
\text { perfectionism, } \\
\text { acculturation, and } \\
\text { stress }\end{array}$ & $\begin{array}{l}\text { International } \\
\text { students } \quad n=76 \\
\text { from } \quad 12 \\
\text { countries in Asia }\end{array}$ & Cross-sectional & $\begin{array}{l}\text { The } \\
\text { American-International } \\
\text { Relations Scale; The 21-item } \\
\text { College Stress Inventory } \\
\text { F-MPS; The 35-item F-MPS } \\
\text { to measure perfectionism }\end{array}$ & $\begin{array}{l}\text { Perfectionism and } \\
\text { acculturation predicted } \\
\text { stress. Perceived prejudice } \\
\text { was the only acculturation } \\
\text { variable that explained any } \\
\text { unique variance in stress. }\end{array}$ \\
\hline (Neri \& Ville, 2008) & Australia & $\begin{array}{l}\text { Investigated how, and } \\
\text { to what extent, } \\
\text { international students } \\
\text { renew their social } \\
\text { networks, and whether } \\
\text { such investments are } \\
\text { positively associated } \\
\text { with academic } \\
\text { performance and well } \\
\text { being }\end{array}$ & $\begin{array}{l}\text { International } \\
\text { students } n=173 \\
\text { from } \quad 27 \\
\text { countries }\end{array}$ & Cross-sectional & $\begin{array}{l}\text { A } 36 \text { questions survey to } \\
\text { measure social capital } \\
\text { renewal, well-being at the } \\
\text { time of arrival, and ended with } \\
\text { some free response questions } \\
\text { which focussed on valued } \\
\text { services that the university } \\
\text { and local community does or } \\
\text { could provide for international } \\
\text { students. }\end{array}$ & $\begin{array}{l}\text { Social networks were not } \\
\text { associated with improved } \\
\text { academic performance but } \\
\text { were associated with } \\
\text { increased well-being. } \\
\text { International students from } \\
\text { 'Western' countries are } \\
\text { happier than students from } \\
\text { non-Western countries. } \\
\text { Many students experienced } \\
\text { relative unhappiness and } \\
\text { disorientation on arrival } \\
\text { from overseas. }\end{array}$ \\
\hline $\begin{array}{l}\text { (Rosenthal, Russell, } \\
\text { \& Thomson, 2008) }\end{array}$ & Australia & $\begin{array}{l}\text { Physical and mental } \\
\text { health well-being } \\
\text { amongst international } \\
\text { students. }\end{array}$ & $\begin{array}{l}\text { Asian, European } \\
\text { and American } \\
n=948\end{array}$ & Cross-sectional & $\begin{array}{l}\text { A measure of state of health } \\
\text { and how this compared to } \\
\text { their health prior to coming to } \\
\text { Australia; The } 42 \text {-item } \\
\text { Depression, Anxiety and } \\
\text { Stress Scales (Lovibond and } \\
\text { Lovibond, 1995); Yes/No } \\
\text { questions about self-harm; } \\
\text { Four questions on experience } \\
\text { of abuse and distress; } \\
\text { Risk-taking behaviour was } \\
\text { assessed in the following } \\
\text { domains: sex-related } \\
\text { practices, drug use, alcohol, } \\
\text { gambling and smoking. }\end{array}$ & $\begin{array}{l}\text { Students reported their } \\
\text { general state of physical } \\
\text { health positively. Students } \\
\text { reported low ratings of } \\
\text { depression, anxiety and/or } \\
\text { stress. Single students were } \\
\text { more anxious than married } \\
\text { students and Asian were } \\
\text { more anxious compared to } \\
\text { non-Asians. } \\
\text { Students who felt their } \\
\text { academic progress was } \\
\text { below expectation had } \\
\text { significantly higher levels of } \\
\text { depression and stress. }\end{array}$ \\
\hline $\begin{array}{c}\text { (Sawir, Marginson, } \\
\text { Deumert, Nyland, \& } \\
\text { Ramia, 2008) }\end{array}$ & Australia & $\begin{array}{l}\text { Loneliness among } \\
\text { international students } \\
\text { in seven university. }\end{array}$ & $\begin{array}{l}\text { International } \\
\text { students from } 30 \\
\text { countries } n= \\
200\end{array}$ & Interview & $\begin{array}{l}\text { different areas touching on the } \\
\text { social and economic e.g. } \\
\text { language, friendship, finance, } \\
\text { were discussed in between } \\
30-50 \text { mins }\end{array}$ & $\begin{array}{l}130 \text { of the participants felt } \\
\text { lonely in the first months. } \\
\text { Language, lack of cultural } \\
\text { fit and personal } \\
\text { characteristics were some of } \\
\text { the causes. However, } 62 \\
\text { participants answered no } \\
\text { trigger. }\end{array}$ \\
\hline
\end{tabular}


Religion was significantly

correlated with

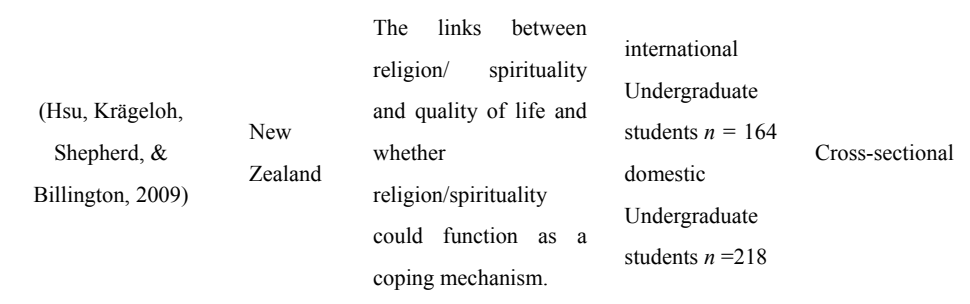

The 26-item Quality of Life questionnaire and a 32-item measure of spirituality (WHOQOL Group, 1998) psychological quality of life

in both groups, and social quality of life in

international students.

Religion/spirituality may act

as a coping mechanism

amongst international

students facing acculturation

stress.

Common elements that Question about challenges, ways to overcome, the Qualitative: positive aspects that you have Group enjoyed in your course? What discussion for 90 would help make your minutes.

many students report include language, adapting to new teaching methodologies, and trying to integrate into a new social setting. would help make your
experience at Flinders better? How supported have you felt during your course here?
Attending workshops and lunch with other students were helpful.

The level of acculturative stress among Asian participants was greater than among European participants. Asian English proficiency scale (3 questions); The 36-item Acculturative stress scale for international students (ASSIS). A measure of Neuroticism (8 items) and Openness to experience (10 items) from the Big Five Inventory; The 22-item Music therapy student academic stress inventory

participants had

significantly higher scores than the Europeans on acculturative stress subscales of perceived discrimination, hate, fear and culture Shock. The number of years lived in the U.S. was not associated with acculturative stress. scoring high in neuroticism may experience higher degrees of stress. On the other hand, scoring high in openness experienced less acculturative stress.

There were no differences A measure of Self-critical perfectionism; The 12-item Discrepancy subscale from the Almost

Perfect Scale; The

(Rice, Choi, Zhang, Morero, \& Anderson, 2012)

$\begin{aligned} & \text { Investigated the } \\ & \text { association }\end{aligned}$ between
$\begin{aligned} & \text { China }(n=129) \\ & \text { self-critical }\end{aligned}$
$\begin{aligned} & \text { and India }(n= \\ & \text { perfectionism, }\end{aligned}$
$\begin{aligned} & \text { acculturative stress, in first } \\ & \text { and depression }\end{aligned}$

between the groups on self-critical perfectionism or depression, but the Chinese students reported higher levels of acculturative stress. Self-critical perfectionism was positively associated with depression for both groups. 


\begin{tabular}{|c|c|c|c|c|c|c|}
\hline $\begin{array}{l}\text { (Gardner, Krägeloh, } \\
\text { \& Henning, 2014) }\end{array}$ & $\begin{array}{l}\text { New } \\
\text { Zealand }\end{array}$ & $\begin{array}{l}\text { To explore the } \\
\text { relationships between } \\
\text { levels of spirituality/ } \\
\text { religiosity, perceived } \\
\text { stress, Quality of life, } \\
\text { and positive and } \\
\text { negative religious } \\
\text { coping. }\end{array}$ & $\begin{array}{l}\text { Domestic } n=45 \\
\text { international } \\
n=65\end{array}$ & Cross-sectional & $\begin{array}{l}\text { The WHOQOL-BREF } \\
\text { contains } 26 \text { items. The } \\
\text { WHOQOL-SRPB consists of } \\
36 \text { items. The Perceived Stress } \\
\text { Scale (PSS). The Brief } \\
\text { Religious Coping Scale (Brief } \\
\text { RCOPE) }\end{array}$ & $\begin{array}{l}\text { International and domestic } \\
\text { students did not differ in } \\
\text { terms of perceived stress. } \\
\text { Muslim students may tend } \\
\text { to use less religious coping } \\
\text { strategies in response to } \\
\text { stress with time. }\end{array}$ \\
\hline $\begin{array}{c}\text { (Hamamura \& Laird, } \\
\text { 2014) }\end{array}$ & $\begin{array}{l}\text { United } \\
\text { States }\end{array}$ & 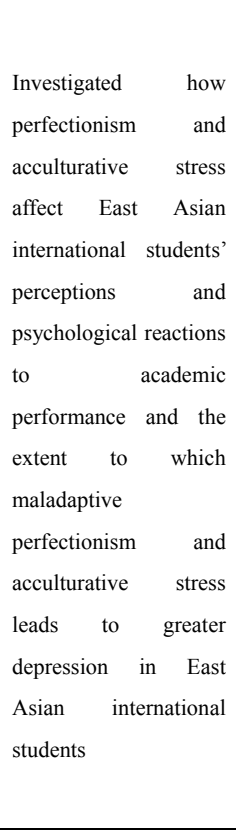 & $\begin{array}{l}\text { East Asian } \\
\text { international } \\
\text { students } n=52 \\
\text { domestic } \\
\text { students } n=126\end{array}$ & Cross-sectional & $\begin{array}{l}\text { The 31-item Almost Perfect } \\
\text { Scale-Revised; The 20-item } \\
\text { Center for Epidemiologic } \\
\text { Studies Depression Scale } \\
\text { (CES-D, 1977); The 36-item } \\
\text { Acculturative Stress Scale for } \\
\text { International Students } \\
\text { (Sandhu \& Asrabadi, 1994); } \\
\text { Academic performance } \\
\text { questionnaire (GPA, their } \\
\text { expected GPA, and their } \\
\text { satisfaction with their GPA) }\end{array}$ & 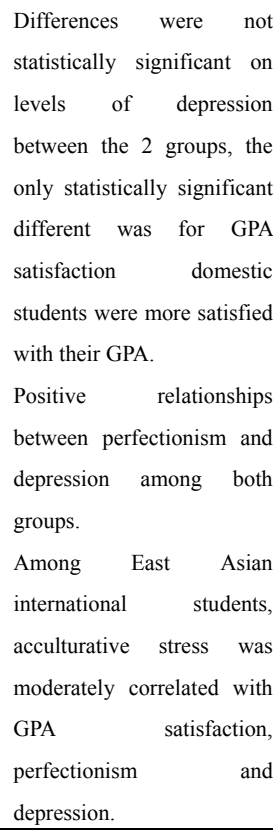 \\
\hline (Liu \& Winder, 2014) & $\begin{array}{l}\text { United } \\
\text { Kingdom }\end{array}$ & $\begin{array}{l}\text { Investigated the } \\
\text { experiences of first } \\
\text { year undergraduate } \\
\text { students. }\end{array}$ & $\begin{array}{l}\text { International } \\
\text { students } n=5 \\
\text { from } 4 \text { countries }\end{array}$ & $\begin{array}{l}\text { Semi-structure } \\
\text { interview } \\
30-66 \text { mins }\end{array}$ & $\begin{array}{l}13 \text { questions cover } \\
\text { reasoning behind studying a } \\
\text { abroad,, participants' } \\
\text { experiences and expectations } \\
\text { and the reactions to change of } \\
\text { culture, difficulties, coping } \\
\text { strategies and relationships. }\end{array}$ & $\begin{array}{l}\text { Social support and } \\
\text { interaction with UK } \\
\text { students paly role in better } \\
\text { adjustment and low level } \\
\text { loneliness. Difficulties } \\
\text { encountered students were } \\
\text { related to cultural } \\
\text { differences, personal } \\
\text { struggles, personality } \\
\text { differences and English } \\
\text { language level. }\end{array}$ \\
\hline (Cho \& Yu, 2015) & $\begin{array}{l}\text { United } \\
\text { States }\end{array}$ & $\begin{array}{l}\text { Investigated the roles } \\
\text { of university support in } \\
\text { determining } \\
\text { international students' } \\
\text { well-being. }\end{array}$ & $\begin{array}{l}\text { International } \\
\text { students } n=131 \\
\text { from } \quad 33 \\
\text { countries }\end{array}$ & Cross-sectional & $\begin{array}{l}\text { Measure of University } \\
\text { identification; The 4-item } \\
\text { organizational identification } \\
\text { scale (Cheney, 1983); A } \\
\text { 5-item university support } \\
\text { scale (Eisenberger et al., } \\
\text { 1986); A 3-item School-life } \\
\text { satisfaction scale (Scott et al., } \\
\text { 1999); A 6-item Student-Life } \\
\text { Stress Inventory (Gadzella, } \\
\text { 1991). }\end{array}$ & $\begin{array}{l}\text { No significant gender } \\
\text { difference on all measures. } \\
\text { No significant effect of } \\
\text { university identification on } \\
\text { psychological stress. } \\
\text { University identification } \\
\text { positively } \\
\text { international students' } \\
\text { perception of university } \\
\text { support and eventually their } \\
\text { school-life satisfaction. } \\
\text { University support increased } \\
\text { international students' } \\
\text { school-life satisfaction and } \\
\text { reduced their psychological } \\
\text { stress. }\end{array}$ \\
\hline
\end{tabular}


Sociocultural adjustment difficulties were highest in the beginning and then decreased.The groups with

\begin{tabular}{|c|c|c|c|c|}
\hline \multirow{6}{*}{$\begin{array}{c}\text { (Hirai, Frazier, \& } \\
\text { Syed, 2015) }\end{array}$} & \multirow{6}{*}{$\begin{array}{l}\text { United } \\
\text { States }\end{array}$} & \multirow{3}{*}{$\begin{array}{l}\text { To test the relationship } \\
\text { between psychological } \\
\text { adjustment and } \\
\text { perceived control over }\end{array}$} & \multicolumn{2}{|l|}{$\begin{array}{l}\text { International } \\
\text { students } n=128\end{array}$} \\
\hline & & & \multirow{2}{*}{$\begin{array}{l}\text { including Asian } \\
(88 \%), \quad \text { White } \\
(7 \%), \text { Hispanic } \\
(3 \%) \text {, and Black }\end{array}$} & \multirow{4}{*}{$\begin{array}{l}\text { Longitudinal } \\
\text { cross-sectional } \\
\text { study with } \\
\text { measures taken } \\
\text { at } 5 \text { time points }\end{array}$} \\
\hline & & & & \\
\hline & & $\begin{array}{lr}\text { academic } & \text { stress, } \\
\text { extraversion } & \text { and }\end{array}$ & $(2 \%)$ & \\
\hline & & $\begin{array}{l}\text { openness, social } \\
\text { connectedness. }\end{array}$ & $\begin{array}{l}* * \text { number of } \\
\text { participants }\end{array}$ & \\
\hline & & & $\begin{array}{l}\text { changed over } \\
\text { the } 5 \text { times. }\end{array}$ & \\
\hline
\end{tabular}

Depression Anxiety

Stress Scale (Lovibond \&

Lovibond, 1995); The 21-item

Well-Being Scale (Ryff,

1989); 7-item Sociocultural

Adaptation Scale (Ward \&

Kennedy, 1999); The 40-item

Academic stress scale (Frazier

et al., 2011); Measures of

Openness, Extraversion, and

Neuroticism; The Social

Connectedness in mainstream

Society and Ethnic

Community Scales (Yoon,

Jung, Lee, \& Felix-Mora,

2012); English proficiency

TOEFL score, and the 12-item

Communication Apprehension

Scale (McCroskey, 1982)

the greatest difficulty

reported more distress,

lower well-being, and

greater sociocultural

difficulty. Perceived control

over academic stress was

one of the most important predictors of psychological

adjustment. Neuroticism

predicted more distress,

lower positive psychological

adjustment, and greater

socio-cultural adaptation.

Openness predicted positive

psychological and socio-

cultural adjustment

trajectories. Extraversion

did not predict any

adjustment outcomes.

Social connectedness with the host member was a significant predictor of positive psychological

adjustment.

\begin{tabular}{|c|c|c|c|c|c|c|}
\hline (Szabo, 2015) & $\begin{array}{l}\text { New } \\
\text { Zealand }\end{array}$ & $\begin{array}{l}\text { To determine if } \\
\text { primary and secondary } \\
\text { coping strategies } \\
\text { moderate the } \\
\text { relationship between } \\
\text { uprooting stress and } \\
\text { anxiety. }\end{array}$ & $\begin{array}{l}\text { Asian } \quad n=61 \\
\text { Western } n=66\end{array}$ & $\begin{array}{l}\text { Short-term } \\
\text { longitudinal } \\
\text { design with three } \\
\text { months } \\
\text { between the two } \\
\text { points of } \\
\text { measurement }\end{array}$ & $\begin{array}{l}\text { A measure of stress (Jose, } \\
\text { Ward, \& Liu, 2007). Four } \\
\text { items measuring uprooting } \\
\text { difficulties. The COPE } \\
\text { Inventory (Carver, Scheier, } \\
\& \text { Weintraub, 1989). } \\
\text { The anxiety and insomnia } \\
\text { subscale of the GHQ-28 } \\
\text { (Goldberg \& Hillier, 1979). A } \\
\text { large variety of measures } \\
\text { related to cross-cultural } \\
\text { adjustment. }\end{array}$ & $\begin{array}{l}\text { Primary coping predicted } \\
\text { more symptoms of anxiety } \\
\text { while secondary coping } \\
\text { reduced the number of } \\
\text { symptoms and buffered the } \\
\text { negative impact of stress. } \\
\text { Asian students reported } \\
\text { significantly less uprooting } \\
\text { stress than Western students. }\end{array}$ \\
\hline $\begin{array}{c}\text { (Hunt, Martens, } \\
\text { Wang, \& Yan, 2016) }\end{array}$ & $\begin{array}{l}\text { United } \\
\text { States }\end{array}$ & $\begin{array}{l}\text { Investigated the } \\
\text { relationship between } \\
\text { acculturative stress, } \\
\text { alcohol use, and } \\
\text { alcohol-related } \\
\text { consequences }\end{array}$ & $\begin{array}{l}\text { International } \\
\text { students } n=175 \\
\text { from different } \\
\text { countries }\end{array}$ & Cross-sectional & $\begin{array}{l}\text { Daily Drinking Questionnaire } \\
\text { (Collins, Parks, \& Marlatt, } \\
\text { 1985); The 24-item Brief } \\
\text { Young Adult Alcohol } \\
\text { Consequences Scale (Kahler, } \\
\text { Strong, \& Read, 2005); The } \\
\text { 36-item Acculturative Stress } \\
\text { Scale (Sandhu \& Asrabadi, } \\
\text { 1994) }\end{array}$ & $\begin{array}{l}\text { No direct affect between } \\
\text { Acculturative stress and } \\
\text { alcohol use but } \\
\text { Acculturative stress } \\
\text { moderated the relationship } \\
\text { between alcohol use and } \\
\text { related consequences. }\end{array}$ \\
\hline
\end{tabular}




\begin{tabular}{|c|c|c|c|c|c|c|}
\hline (Redfern, 2016) & Australia & $\begin{array}{l}\text { Investigated the } \\
\text { prevalence of negative } \\
\text { psychological } \\
\text { symptoms, (stress, } \\
\text { anxiety, and } \\
\text { depression). }\end{array}$ & $\begin{array}{l}\text { Australian } \\
\text { undergraduates } \\
\text { students } n=98 \\
\text { Chinese } \\
\text { undergraduates } \\
\text { students } n=103\end{array}$ & $\begin{array}{l}\text { Mixed method } \\
\text { (Questionnaire } \\
\text { and open-ended } \\
\text { questions) }\end{array}$ & $\begin{array}{l}\text { An open-ended item for } \\
\text { subjects to describe the main } \\
\text { sources of stress anxiety in } \\
\text { their life. } \\
\text { Depression Anxiety Stress } \\
\text { Scale (42-items; Lovibond \& } \\
\text { Lovibond, 1995b) }\end{array}$ & $\begin{array}{l}\text { Chinese students' levels of } \\
\text { both stress and anxiety were } \\
\text { significantly higher than for } \\
\text { local students. Academic, } \\
\text { life balance, and family } \\
\text { factors were found to be the } \\
\text { main sources of stress for } \\
\text { Chinese students. }\end{array}$ \\
\hline $\begin{array}{c}\text { (Huang \& Mussap, } \\
\text { 2016) }\end{array}$ & Australia & $\begin{array}{l}\text { Investigated the } \\
\text { relationship between } \\
\text { trait maladaptive } \\
\text { perfectionism, } \\
\text { acculturative stress, } \\
\text { years in Australia and } \\
\text { depressive symptoms. }\end{array}$ & $\begin{array}{l}\text { International } \\
\text { students } n=384 \\
\text { from } 17 \text { Asian } \\
\text { countries }\end{array}$ & Cross-sectional & $\begin{array}{l}\text { The 36-item Acculturative } \\
\text { Stress Scale for International } \\
\text { Students; The } 23 \text {-item } \\
\text { Almost Perfect Scale Revised } \\
\text { (APS-R). The } 20 \text {-item Centre } \\
\text { for Epidemiological Studies } \\
\text { Depression Scale. }\end{array}$ & $\begin{array}{l}\text { Acculturative stress and } \\
\text { maladaptive directly } \\
\text { associated with increased } \\
\text { depressive symptoms. }\end{array}$ \\
\hline $\begin{array}{c}\text { (Praharso, Tear, \& } \\
\text { Cruwys, 2017) }\end{array}$ & Australia & $\begin{array}{l}\text { Investigated the } \\
\text { relationship between } \\
\text { social connectedness, } \\
\text { stress, and wellbeing. }\end{array}$ & $\begin{array}{l}\text { International } \\
\text { students } n=79\end{array}$ & $\begin{array}{l}\text { Longitudinal } \\
\text { study with two } \\
\text { time points. At } \\
\text { the start of the } \\
\text { semester (T1) } \\
\text { and at the end of } \\
\text { the semester } \\
\text { (T2) } \\
\text { approximately } \\
\text { four months later }\end{array}$ & $\begin{array}{l}\text { A 4-item Social support scale } \\
\text { (House, 1981) } \\
\text { An adapted version of the } \\
\text { Groups Listing Task to } \\
\text { determine important group } \\
\text { memberships. (Haslam et al., } \\
\text { 2008); The 42-item stress } \\
\text { subscale of the Depression, } \\
\text { Anxiety and Stress Scales } \\
\text { (Lovibond and Lovibond, } \\
\text { 1995); The 5-item Satisfaction } \\
\text { with Life Scale (Diener et al., } \\
\text { 1985); The 7-item depression } \\
\text { subscale of the Depression } \\
\text { Anxiety Stress Scales } \\
\text { (DASS-21) }\end{array}$ & $\begin{array}{l}\text { There was limited evidence } \\
\text { for the buffering role of } \\
\text { social support as predicted } \\
\text { by the Stress Buffering } \\
\text { Hypothesis. A loss of social } \\
\text { identities as result of } \\
\text { transition had a subsequent } \\
\text { decline in wellbeing level. }\end{array}$ \\
\hline
\end{tabular}

\section{Copyrights}

Copyright for this article is retained by the author(s), with first publication rights granted to the journal.

This is an open-access article distributed under the terms and conditions of the Creative Commons Attribution license (http://creativecommons.org/licenses/by/4.0/). 